\title{
Expedition 314 summary $^{\mathbf{1}}$
}

H. Tobin, M. Kinoshita, Moe Kyaw Thu, and the Expedition 314 Scientists $^{2}$

\section{Chapter contents}

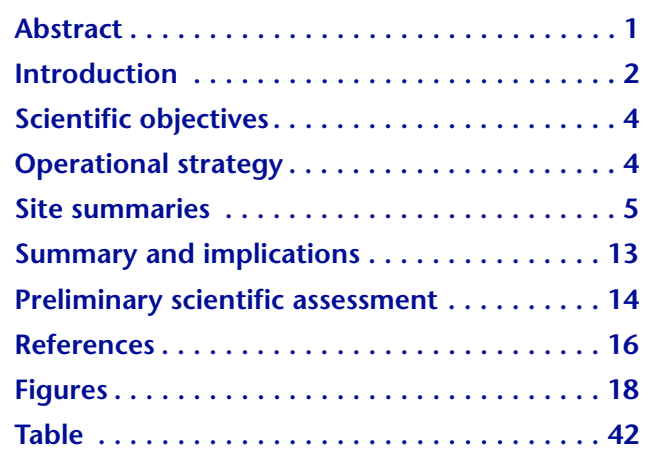

${ }^{1}$ Tobin, H., Kinoshita, M., Moe, K.T., and the Expedition 314 Scientists, 2009. Expedition 314 summary. In Kinoshita, M., Tobin, H., Ashi, J., Kimura, G., Lallemant, S., Screaton, E.J., Curewitz, D., Masago, H., Moe, K.T., and the Expedition 314/315/316 Scientists, Proc. IODP, 314/315/316: Washington, DC (Integrated Ocean Drilling Program Management International, Inc.). doi:10.2204/iodp.proc.314315316.111.2009 'Expedition 314/315/316 Scientists' addresses.

\section{Abstract}

Integrated Ocean Drilling Program (IODP) Expedition 314 was a milestone, both as the inaugural scientific drilling mission of the new vessel, the $\mathrm{D} / \mathrm{V}$ Chikyu, and as the first step in the multistage Nankai Trough Seismogenic Zone Experiment (NanTroSEIZE), an ambitious, coordinated, multiplatform, and multiexpedition drilling project designed to investigate fault mechanics and seismogenesis along subduction megathrusts through direct sampling, in situ measurements, and long-term monitoring.

During Expedition 314, our primary goals were to obtain a comprehensive suite of geophysical logs and other downhole measurements at sites along a transect from the incoming plate to the Kumano forearc basin using state-of-the-art logging-while-drilling (LWD) technology. Drilling and logging was successfully completed at four sites, ranging in total depth below seafloor from 400 to $1400 \mathrm{~m}$, with partial success at a fifth site. These sites included (1) the frontal thrust and toe region of the outer accretionary prism near the trench; (2) the fault zone, associated thrust sheet, and foot wall of a major out-of-sequence thrust system (the "megasplay" fault); and (3) $1 \mathrm{~km}$ thick forearc basin deposits and highly deformed rocks of the interior of the older accretionary prism. The principal objectives of the LWD program were to document in situ physical properties; stratigraphic and structural features; sonic to seismic scale velocity data for core-log-seismic integration; and stress, pore pressure, and hydrological parameters through both scalar and image logging measurements. All four sites have since undergone core sampling during subsequent IODP NanTroSEIZE Expeditions 315 and 316.

Depth objectives for this expedition ranged from $~ 400$ to 1400 meters below seafloor. Logging included measurement of gamma ray values, azimuthal gamma ray density, neutron porosity, full waveform sonic velocity, azimuthal resistivity imaging, zero-offset vertical seismic profile, ultrasonic caliper, and annular fluid pressure and temperature, although not all logs in this suite were collected at all sites.

Principal results of Expedition 314 include the following:

1. Present-day stress varies markedly along the NanTroSEIZE transect, and stresses in the upper $1.4 \mathrm{~km}$ are strongly compressional in the outer, active accretionary prism but extensional in the forearc basin. 
2. The megasplay thrust sheet is composed of highly deformed and fractured rocks that are anomalously well indurated relative to their present depth.

3. The occurrence of gas hydrate as a cement preferentially located in sandy portions of turbidite beds above a bottom-simulating reflector was quantified.

4. Drilling at Sites C0001 and C0002 also provided important pilot hole information that will help prepare for deep-riser sites planned for later stages of NanTroSEIZE drilling.

5. The main frontal thrust and main splay fault zone, imaged at Sites C0004 and C0006, respectively, are intervals of strong fracturing and brecciation several to ten meters in thickness. At these two sites, there are differing contrasts in physical properties within and below the fault zones.

\section{Introduction}

The Nankai Trough Seismogenic Zone Experiment (NanTroSEIZE) is a multiyear, multistage, and multiplatform effort planned for the Integrated Ocean Drilling Program (IODP). The first of four stages of NanTroSEIZE drilling operations comprises three individual expeditions $(314,315$, and 316) conducted by the new riser-capable drilling vessel, the $\mathrm{D} / \mathrm{V}$ Chikyu, from September 2007 to February 2008. The original primary objectives of Expedition 314 were to obtain a comprehensive suite of geophysical logs and other downhole measurements at six sites (Figs. F1, F2, F3, F4) using state-of-the-art logging-whiledrilling (LWD) technology. These six sites are designed to accomplish the principal goals of the NanTroSEIZE Science Plan, including documenting the material inputs to the subduction conveyor (fluid, solids, and heat), the properties of major thrust faults and their wall rocks at depths shallower than $\sim 1.4 \mathrm{~km}$, and the geology of the accretionary prism and overlying slope basin sediments (Tobin and Kinoshita, 2006a; Kinoshita et al., 2006). Four of these six sites were in fact drilled and logged during Expedition 314, and all four have been cored during the two subsequent Expeditions 315 and 316.

During Expedition 314, we acquired borehole LWD data by drilling dedicated holes using a drill string with the logging instruments incorporated into drill collars just above the drilling bit (Fig. F5). A number of previous Ocean Drilling Program (ODP) and IODP expeditions have employed LWD technology (Riedel et al., 2006; Flemings et al., 2006; Tréhu, Bohrmann, Rack, Torres, et al., 2003; Mikada, Becker, Moore,
Klaus, et al., 2002; Kelemen, Kikawa, Miller, et al., 2004). We deployed Schlumberger LWD-measurement-while-drilling (MWD) tools including the following:

- geoVISION: records formation resistivity, including $360^{\circ}$ borehole resistivity imaging and spectral natural gamma radiation.

- adnVISION: mainly records neutron porosity and gamma ray density.

- sonicVISION: provides sonic $P$-wave velocity.

- seismicVISION: records check shot vertical seismic profile (VSP) arrivals during LWD drilling and therefore provides interval $P$-wave velocity.

Additional measurements primarily intended for monitoring drilling conditions (MWD), such as torque, downhole weight on bit (WOB), borehole pore fluid pressure (annular pressure while drilling $[A P W D])$, and other parameters, were recorded and transmitted in real time using MWD uphole telemetry.

Expedition 314 was entirely dedicated to the LWD effort, and only minor coring and no other downhole measurement operations took place. Logging data were initially analyzed by the Shipboard Scientific Party and made available to the scientific parties of the other NanTroSEIZE Stage 1 expeditions.

\section{Geological setting}

The Nankai Trough is a subducting plate boundary where the Philippine Sea plate underthrusts the southwestern Japan margin at a rate of $\sim 4.1-6.5 \mathrm{~cm} / \mathrm{y}$ along an azimuth of $300^{\circ}-315^{\circ} \mathrm{N}$ (Seno et al., 1993; Miyazaki and Heki, 2001; Heki, 2007) down an interface dipping $3^{\circ}-7^{\circ}$ (Kodaira et al., 2000). The subducting lithosphere of the Shikoku Basin was formed by backarc spreading at 15-25 Ma (Okino et al., 1994). The Nankai subduction zone forms a near end member sediment-dominated accretionary prism. In the toe region off Kumano, a sedimentary section nearly $2 \mathrm{~km}$ thick arrives at the deformation front (Park et al., 2002).

The three major seismic stratigraphic sequences identified in the northern Shikoku Basin are the lower and upper Shikoku Basin sequences and the Quaternary turbidite sequences. The upper Shikoku Basin facies off Kumano decreases modestly in thickness toward the north, whereas the lower Shikoku Basin facies displays a much more complicated geometry as a result of the effects of basement topography (Le Pichon et al., 1987a, 1987b; Mazzotti et al., 2000; Moore et al., 2001). Seismic thickness decreases above larger basement highs and a more transparent acoustic character indicates local ab- 
sence of sandy turbidite packages that characterize most other parts of the lower Shikoku Basin. The mechanical differences between subducting basement highs and subducting basement plains could be significant for fault zone dynamics and earthquake rupture behavior.

Deformation front behavior off Kumano is fundamentally different than it is at previous targets of ODP drilling off Muroto or Ashizuri, several hundred kilometers to the southwest. Seismic reflection data off Kumano clearly delineate the frontal fault near the prism toe; however, there is little evidence for seaward propagation of the décollement within deeper Shikoku Basin strata (see "Proposal 603AFull2" at www.iodp.org/nantroseize-downloads). One interpretation of the seismic profiles is that the décollement steps up to the seafloor, thereby thrusting an older accretionary prism package (upper Shikoku Basin facies?) over the upper Quaternary trench-wedge facies. Manned submersible observations also indicate that semilithified strata of unknown age have been uplifted and exposed along a fault scarp at the prism toe (Ashi et al., 2002). Farther landward, the fault ramps down into the lower Shikoku Basin facies (Park et al., 2002).

The lower forearc slope consists of a series of thrust faults that have shortened the accreted sedimentary units of the accretionary prism. A combination of swath bathymetric and multichannel seismic (MCS) data show a pronounced continuous outer ridge (outer arc high) of topography extending $>120 \mathrm{~km}$ along strike, which may be the result of uplift related to megasplay fault slip, including the 1944 Tonankai M 8.2 earthquake (e.g., Ichinose et al., 2003) and repeated previous earthquakes. Remotely operated vehicle (ROV) and manned submersible diving surveys along this feature reveal a very steep slope on both sides of the ridge (Ashi et al., 2002; unpubl. data). The outer arc high coincides with the updip end of the splaying system of thrust faults that branch from a strong seismic reflector interpreted by Park et al. (2002) as a major out-of-sequence thrust, which we term the "megasplay" because it is a feature that traverses the entire wedge and has had a protracted history shown by the thick forearc basin trapped behind its leading edge (Moore et al., 2007). The megasplay is hypothesized to represent the mechanical boundary between the inner and outer portions of the accretionary prism and between aseismic and seismogenic fault behavior (Wang and $\mathrm{Hu}, 2006$ ). At depth this megasplay is a high-amplitude reflector (Fig. F3), and it branches into a family of thrust splays in the upper few kilometers below the seafloor, prominently including the thrust splay drilled on this expedition at Site C0004.

The most direct evidence for recent megasplay fault activity comes from stratigraphic relationships at the tips of faults in young slope sediments. Direct fault intersections with the seafloor are not generally observed (Moore et al., 2007); however, the thrust sheets wedge into these slope deposits, causing tilt and slumping of even the strata nearest to the surface.

Other direct evidence that the megasplay fault has been active in geologically recent time comes from Kumano forearc basin stratigraphy. The Kumano Basin is characterized by flat topography at $\sim 2000 \mathrm{~m}$ depth and is filled with turbiditic sediments to a maximum thickness of $2000 \mathrm{~m}$. Little is known regarding the detailed stratigraphy of the Kumano Basin, but several remarkable features are recognized in seismic profiles (Fig. F6). The overall sedimentary sequences filling the basin can be divided into four main units by unconformities based on seismic reflection stratigraphy. Sediments in the southern part of the basin are tilted northward, truncated by a flat erosional surface, and subsequently cut by normal faults (Park et al., 2002). The depositional center appears to have migrated northward after each successive unconformity.

Sequences above the unconformities are tilted less than those below the unconformities. All sediments pinch out toward the north. All of these features appear to be caused by uplift of the outer rise (Park et al., 2002).

\section{Seismic studies/Site survey data}

The off-Kii and Kumano Basin region is among the best-studied subduction zone forearcs in the world. A significant volume of site survey data has been collected in the drilling area over many years, including multiple generations of two-dimensional (2-D) seismic reflection (e.g., Park et al., 2002), wide-angle refraction (Nakanishi et al., 2002; Nakanishi et al., 2008), passive seismicity (e.g., Obana et al., 2005), heat flow (Kinoshita et al., 2003), side-scan sonar, and swath bathymetry as well as submersible and ROV dive studies (Ashi et al., 2002).

In 2006, a joint, three-dimensional (3-D) seismic reflection survey was conducted by Japanese and U.S. scientists over an $\sim 11 \mathrm{~km} \times 55 \mathrm{~km}$ area, acquired under contract by Petroleum GeoServices (Fig. F2) (Moore et al., 2007). The poststack trace spacing is $12.5 \mathrm{~m}$ in the inline direction and $18.75 \mathrm{~m}$ in the cross-line direction. Subsequently, this data volume 
was processed using 3-D prestack depth migration techniques, yielding the high-resolution depth sections in this volume. This 3-D volume-the first deep-penetration, fully 3-D marine survey ever acquired for basic research purposes-has been used to refine the selection of drill sites and targets in the complex megasplay fault region and to define the regional structure and seismic stratigraphy. As drilling proceeded, 3-D seismic data were used in conjunction with logging and VSP results to analyze physical properties of the subsurface, to expand findings in the boreholes to wider areas, and to assess drilling safety.

\section{Scientific objectives}

The over arching objective of the LWD program was to provide borehole data that will be used in conjunction with cores to document the geology, physical properties, mechanical state, fluid content, and stress conditions at the drilling site locations. Specifically, we wanted to document the following:

- Physical properties. We planned to record density, porosity, resistivity, and sonic velocity for each borehole. These logs provide key in situ information that, together with core-based sample data, will be used to quantify the mass and materials that make up the Nankai margin. Drilling targets for which physical properties are especially relevant include zones of anomalous compaction state, gas hydrate bottom-simulating reflectors (BSRs), and fault zones and adjacent wall rocks. In practice, we were able to obtain all of these types of logging data, but not all types from every site drilled. In particular, the lack of a neutron source during drilling of Sites C0004 and C0006 prevented us from acquiring porosity and density measurements and tool failure limited sonic data from Site C0006 to only the shallow portion of the hole.

- Lithology. We also recorded natural gamma ray data. Together with the logs described above, these data were used to develop an integrated logbased lithologic characterization and logging unit definition.

- Structural geology. Borehole imaging logs, principally azimuthal resistivity, permitted interpretation of bedding dip, fracture presence and orientation, and other rock fabric data, which will be useful in conjunction with core data to develop a complete structural description, including in situ orientation of structures.

- In situ fluid pressure and stress. Borehole imaging logs were also used to detect borehole breakouts and drilling-induced tensile fractures (e.g., McNeill et al., 2004; Wu et al., 2007), which are useful for determining the orientation of the present-day horizontal principal stress axes. The APWD $\log$ is primarily a drilling parameter measurement, as it measures the fluid pressure in the open borehole near the bit; however, it can be an indicator of steep gradients in formation pressure or other anomalies. Sonic velocity is potentially another indirect indicator of stress and pore pressure conditions.

- Core-log-seismic integration. Several of the logs provided key information for creating synthetic seismograms that tie 3-D seismic attributes to cores and borehole depth. The seismic while drilling (SWD), essentially a check shot-style VSP, is principal among these and provides borehole depth ties at similar wavelengths to that of the MCS data.

- Drilling conditions. APWD, WOB, torque, drilling rate, and other parameters are primarily used to assess the drilling conditions. However, these measurements can provide useful information about formation strength, presence of faults, and other environmental variables relevant to the scientific objectives and also relevant for planning the well drilling and casing program for subsequent riser drilling.

\section{Operational strategy}

To achieve the overall scientific objectives of the NanTroSEIZE project, drilling has been planned for six primary sites and two contingency sites, targeting the incoming plate section, the frontal thrust of the accretionary wedge, the megasplay fault system at different depths, and the plate interface in the seismogenic zone. See Tobin and Kinoshita (2006a) for details of the four-stage plan to complete these objectives. NanTroSEIZE Stage 1 plans called for drilling and sampling in riserless mode at six of the sites during Expeditions 314-316, including

- The incoming sediments of Shikoku Basin (two sites),

- The frontal thrust system at the toe of the accretionary wedge,

- The midwedge megasplay fault system, and

- The uppermost $1000-1400 \mathrm{~m}$ at the two sites planned for later deep penetrations of the seismogenic zone faults by riser drilling.

\section{Primary drill sites}

During Expedition 314 the planned order of drilling at the six sites was determined by scientific priority 
and operational difficulty. The original plan was to drill at proposed Site NT1-01A to the top of basement at $\sim 600$ meters below seafloor (mbsf). Next we would continue to proposed Site NT2-03B to drill at $\sim 1000$ mbsf into the splay fault thrust sheet, drill to 1400 mbsf at the future deep riser hole at proposed Site NT3-01B, drill to 1000 mbsf to pass through the splay fault reflector and into the footwall within accretionary prism at proposed Site NT2-01B, drill to $950 \mathrm{mbsf}$ at the frontal thrust site at proposed Site NT1-03A, and finish with $1200 \mathrm{~m}$ of drilling to reach the top of the oceanic crust at proposed Site NT107A (Kinoshita et al., 2007) (Figs. F7, F8).

Because of concerns regarding geological hazards, operations to drill two pilot holes at proposed Sites NT2-03B and NT1-03A were added to the operational plan prior to drilling with LWD-MWD tools at the six primary sites. In addition, geotechnical coring of the top section of the future Stage 2 riser hole at proposed Site NT2-03A was added to the plan, owing to urgency to obtain strength data for riser wellhead deployment.

During the course of drilling, delays occurred during many of the early operations; therefore, the original plan was modified to drill LWD sites right after the first pilot Hole C0001A. Holes C0001B, C0001C, and C0001D were subsequently drilled at Site C0001, and Holes C0002A and C0003A followed. After the loss of the LWD-MWD bottom-hole assembly (BHA) while drilling at Site C0003 (see "Site C0003"), the drilling plan was modified again because it was deemed operationally necessary to drill pilot holes with either ROV monitoring of the drill site at the seafloor and/or MWD-only measurements to ensure hole safety. Three pilot holes without any LWDMWD tools (Holes C0004A, C0005A, and C0005B) and one LWD hole (C0004B) were drilled in the vicinity of proposed Site NT2-01. After this, the ship moved to the proposed Site NT1-03B area and drilled one pilot hole with MWD tools (Hole C0006A) and one LWD hole (C0006B) to complete the expedition.

During the planning stage, 22.5 contingency days were factored into the expedition for typhoons, mechanical downtime, and casing operations at proposed Sites NT2-03B and NT2-01D. However, actual days used for each site and operations during the expedition were generally quite different from the original plan. Failure and repair of the dynamic positioning system, fishing for the stuck BHA and cementing operations in Hole C0003A, and numerous other operational delays such as ROV maintenance; Kuroshio current-related operations; and checking and maintaining rig-floor, guidehorn, and derrick mechanical systems at intervals were responsible for the differences.

\section{Logging strategy}

Difficulties in attempted wireline logging during previous legs at Nankai and other accretionary prisms and, conversely, the successful experience of ODP Leg 196 (Mikada, Becker, Moore, Klaus, et al., 2002) at Nankai and other previous LWD expeditions (Shipley, Ogawa, Blum, et al., 1995; Kimura, Silver, Blum, et al., 1997; Moore, Klaus, et al., 1998; Mikada, Becker, Moore, Klaus, et al., 2002; Austin, Christie-Blick, Malone, et al., 1998; O'Brien, Cooper, Richter, et al., 2001; Binns, Barriga, Miller, et al., 2002; Tréhu, Bohrmann, Rack, Torres, et al., 2003) clearly indicated that LWD was best suited to acquire in situ physical property data in the Nankai accretionary prism.

During Expedition 314 we employed both LWD and MWD technologies. LWD and MWD tools measure different parameters. LWD tools are formation evaluation tools used while drilling that measure formation properties with instruments located in the drill collars above the drill bit. MWD tools are also located in the drill collars but measure downhole engineering drilling parameters (e.g., WOB, torque, etc.). Another function of the MWD tool is transmitting real-time MWD data and a limited set of LWD data through drilling fluid inside the drill pipe by means of a modulated pressure wave ("mud pulsing"), which is then monitored in real time at the rig floor and by the scientific party. Most LWD data (at least those of highest resolution and thus larger data volume) are recorded in memory at the downhole tool and retrieved when the tool returns to the surface. For safety monitoring purposes, the MWD tool was coupled with APWD during this expedition. MWD tools enable both APWD and MWD data to be transmitted uphole when the tools are used together, along with a subsample of the LWD data.

\section{Site summaries}

\section{Site $\mathrm{C} 0001$}

Site C0001 is located at the seaward edge of the Kumano Basin uplift (outer arc high), where the megasplay fault system branches and approaches the surface (Fig. F9, F10). Drilling at this site during Expedition 314 targeted the uppermost 1000 mbsf to access the thrust sheets uplifted by several branches of the megasplay fault, as well as a thin overlying slope cover sequence. The principal objective was to ob- 
tain LWD logging and SWD data in this section. In addition, this was a pilot operation for planned later riser drilling at this site to 3200 mbsf to access multiple branches of the megasplay fault system during the first riser drilling program of IODP.

\section{Log characterization and lithologic interpretation}

Three logging units and eight logging subunits were defined based on data from Hole C0001D (Fig. F11). Logging Unit I (0-198.9 m LWD depth below seafloor [LSF]) is characterized by gradually increasing resistivity and decameter-scale gamma ray cycles. It is interpreted as slope sediments composed of silt turbidites and mud. No clear sedimentary features could be recognized in the images. Logging Subunit IB (190.5-198.9 m LSF) is thought to represent a basal coarse sediment layer and an unconformity at the base of the slope sediments and is characterized by positive peaks in the resistivity logs and a broad negative peak in the gamma ray log, suggesting washout of a possible sandy/silty layer. Logging Unit II (198.9-529.1 m LSF) exhibits higher gamma ray and resistivity baselines, suggesting an increase in clay content. The near-continuous breakouts suggest this unit is composed of relatively homogeneous hemipelagic mud and silt turbidites. Logging Unit III (529.1-976 m LSF) shows distinct differences from logging Units I and II. Gamma ray values, resistivity, and velocities are all increased. This unit also contains highly fractured resistive zones and few to no breakouts. Logging Units II and III are both interpreted as accretionary prism sediments forming part of the megasplay fault thrust sheet.

\section{Physical properties}

All LWD resistivity logs show a general downhole increasing trend. A comparison shows that ring resistivity is systematically higher than bit resistivity. The profile of resistivity presents a net downward decreasing step at the $198.9 \mathrm{~m} \mathrm{LSF}$ logging Unit I/II boundary and two significant zones of lower resistivity values at 529-628 $\mathrm{m} \mathrm{LSF}$ in a disrupted zone (see below) and at 815-855 m LSF (Fig. F11). Sonic $P$ wave velocity generally increases with depth. Gradients of velocity with depth are $0.757,0.976$, and $1.793 \mathrm{~m} / \mathrm{s}$ per meter for logging Units I, II, and III, respectively. The 198.9 m LSF logging Unit I/II boundary is characterized by relatively low velocities. Five major low-velocity zones (529-600, 660-695, 773$827,884-894$, and 915-965 $\mathrm{m}$ ) depart from the increasing trend of velocity in logging Unit III, the first zone corresponding to the aforementioned disrupted zone.

Because the adnVISION tool failed during drilling and LWD operations, the real-time monitoring density (RHOB) and porosity (TNPH) data could only be retrieved from the uppermost $506 \mathrm{~m}$ LSF. Those data suffer from large scattering. Real-time density generally increases with depth. At the logging Unit I/II boundary the log shows a sudden drop of value. Below this boundary, density values gradually increase, with the notable exception of the zone from 470 to $490 \mathrm{~m}$, where density values decrease. The neutron porosity curve shows the opposite trend and the same anomalous zone. Porosity estimation from resistivity data was calibrated using the data from Sites 808, 1175, and 1176 of ODP Leg 196 at the Muroto transect (Taira et al., 1991; Moore et al., 2001). Its profile presents a net step increase at $200 \mathrm{~m}$ LSF and two zones of increased porosity departing from the general decreasing trend (468-633 and 810-910 m LSF). That resistivity-derived porosity fits only with the lowest values of density-derived porosity calculated from the RHOB log, probably a result of poor log quality in an enlarged borehole. Crossplots show good correlation between velocity and resistivity-derived porosity and between velocity and resistivityderived density.

\section{Structural geology and geomechanics}

Resistivity images provide constraints on structural development and stress orientations at Site C0001. Breakouts and associated tensile fractures are a striking feature of the upper half of the borehole and indicate a maximum horizontal stress orientation of $335^{\circ}$ (Fig. F11). This horizontal stress is more northerly than both the Philippine Sea-Japan plate convergence vector and the geodetically determined shortening direction on the Kii Peninsula (Heki, 2007). The maximum horizontal stress is nearly perpendicular to the strike trend of the accretionary prism and major faults and is consistent with prismnormal shortening. The difference between the maximum horizontal stress at Site C0001 and the orientation of local plate convergence suggests oblique convergence or right lateral strike-slip faulting elsewhere in the forearc region.

Bedding and fracture orientations are consistent with deformation around an axis parallel to the trend of the accretionary prism. That is, poles to bedding form a girdle trending north-northwest. Fractures are more complex with shallower orientations having northwest and southeast dips. A set of near- 
vertical conductive natural fractures trend northnorthwest, are cut by younger normal faults, and may have been dilated by drilling operations, as inferred from the observation of wide conductive zones. Bedding dips are locally steeper at the contact between the slope deposits and the accretionary prism, but faulting is not evident at this apparent unconformity.

A zone of difficult drilling from 529 to $629 \mathrm{~m} \mathrm{LSF}$ shows patterns of bedding disruption typical of fault zones. Increasing consolidation across this zone of disruption may be interpreted as resulting from normal faulting; however, nontypical geometries of thrust faulting are also consistent with this consolidation state.

\section{Log-seismic correlation}

Logging Unit I corresponds to the hemipelagic slope sediments between the seafloor and $\sim 200 \mathrm{~m}$ seismic depth below seafloor (SSF) (Figs. F9, F11). Logging Subunit IB corresponds to a thin low-amplitude reflection overlying the strong positive reflection at $200 \mathrm{~m}$ SSF that defines the base of logging Unit I. Logging Unit II corresponds to a zone of southeastdipping, generally low amplitude reflections. Reflections intersect the borehole at the logging Subunit IIA/IIB and IIB/IIC boundaries, but there is no change in the general character of the seismic data across these reflections. The boundary between logging Units II and III correlates with a change in reflectivity from relatively low amplitude above the boundary to relatively high amplitude below. Logging Subunit IIIA corresponds to a series of high-amplitude, laterally continuous reflections that appear on the southeast side of the borehole and are cut off by the inferred fault that intersects the borehole at the base of this subunit.

Check shot data to $635 \mathrm{~m}$ LSF provided good constraint on the long wavelength velocity depth conversion. These data demonstrated that the prestack depth-migrated (PSDM) velocity model at the site was quite good. We found it difficult to reconcile the strong reflection at the boundary between the slope basin section and the accretionary wedge below with the log observations in the hole. Synthetic seismograms of this interval fail to reproduce the strong reflection because of the lack, in the logs, of an abrupt increase in acoustic impedance just above the boundary.

In summary, a $976 \mathrm{~m}$ interval made up primarily of apparently strongly deformed mudstones with some silty to sandy turbiditic sediments was drilled and logged at Site C0001. This section is the thrust sheet of one main branch of the megasplay fault system, including an overlying $200 \mathrm{~m}$ of slope basin deposits. Logging and vertical seismic data provide the first information on the physical properties, lithology, structure, and state of stress in this key element of the Nankai subduction system, the upper 480 mbsf of which was cored on subsequent Expedition 315 (see the "Expedition 314 Site C0001" chapter).

\section{Site $\mathrm{C0002}$}

Site C0002 is located at the Kumano forearc basin off the Kii Peninsula (Fig. F12). The goal of drilling at this site was to $\log$ the $\sim 1000 \mathrm{~m}$ thick Kumano forearc basin section and several hundred meters of the underlying formations, interpreted as older rocks of the accretionary prism and/or early slope basin sediments deposited prior to the development of the megasplay fault. This site is also slated for deep riser drilling across the entire plate boundary system to $>5500$ mbsf during a later stage. We were able to drill and $\log$ the entire section from 0 to 1401 mbsf with complete success. An excellent suite of logs and seismic VSP data reveals the structure of the forearc basin, the gas hydrate-bearing zone, and the underlying deformed rocks of the inner accretionary prism.

\section{Log characterization and lithologic interpretation}

Four logging units were defined based on the trends and character in the full suite of LWD log responses (Fig. F13). Each logging unit is bounded by dip discontinuities interpreted as angular unconformities. There is also an angular unconformity within logging Unit III but not a sufficient change in log character to require division of the logging unit. Overall, logging Unit I is interpreted to be slope basin deposits. Logging Units II and III are interpreted as thick basin fill dominated by repeating turbidite deposits, as seen clearly on the log responses, particularly the gamma ray log. Within logging Unit II are two zones of particular interest defined by changes in log responses. Zone A (218.1-400.4 m LSF) is interpreted as a gas hydrate-bearing zone based on the resistivity profiles, with gas hydrates concentrated in the sandy horizons of the turbidite deposits. Zone B (481.6$547.1 \mathrm{~m} \mathrm{LSF}$ ) is interpreted as a potential gas-bearing interval, again within the sandy horizons of the turbidite deposits. The presence of gas is based on the sonic log response across the zone. Logging Unit III is a homogeneous clay-rich interval of mudstone, immediately overlying the top of the older accretionary prism section that forms basement to the basin at $936 \mathrm{~m}$ LSF. Logging Unit IV, from 936 to 1401 $\mathrm{m}$, corresponds with the accretionary prism imaged on the seismic profiles, exhibiting a distinct change 
to much more variable responses in virtually all of the logs.

\section{Physical properties}

Physical properties in Hole C0002A show very different behaviors for different lithologies, which are classified based not only on the main logging units (slope sediment units and underlying prism) but also on different stratigraphic zones identified. Almost all physical properties are relatively well determined in the forearc basin sediments, whereas they exhibit a wide range of scatter in the underlying prism section, probably as a result of poor borehole conditions. However, properties not sensitive to hole condition (e.g., bit and deep resistivity) suggest that the accretionary prism is denser and more compacted compared to the forearc basin (Fig. F13). The lower part of the forearc basin below $400 \mathrm{~m} \mathrm{LSF}$ at the BSR is characterized by physical properties that suggest a relative undercompaction: slightly decreasing or nearly constant resistivity with depth while velocity increase is insignificant and changes in density and porosity are relatively limited. Above the BSR (Zone A), a signature of gas hydrate is indicated by a strongly increasing overall resistivity trend with depth, showing numerous local spikes of high resistivity, whereas changes in neutron porosity and density are minor. Gas hydrate-bearing formations are characterized by a unique velocity and resistivity relation because of a significant increase in resistivity but a muted increase in velocity with depth.

\section{Structural geology and geomechanics}

Structure is distinct between the forearc basin and underlying accretionary prism at Site $\mathrm{C0002}$ (Fig. F13). However, orientations of bedding planes and borehole breakouts are consistent (northeast-southwest and northwest-southeast, respectively) throughout the entire borehole. Bedding dips are gentle $\left(<10^{\circ}-15^{\circ}\right)$ in the forearc basin with some variation in dip direction with depth, which agrees well with seismic reflection data. Dips increase to values of $\sim 30^{\circ}-60^{\circ}$ toward and within logging Unit IV, the older accretionary prism. Natural fractures are rarer than at Site C0001 and have scattered orientations within the basin but a more consistent northeastsouthwest trend within the prism. All fractures dip between $30^{\circ}$ and $85^{\circ}$ with no significant difference between basin and prism. Basin fractures have three dominant trends: northeast-southwest, east-west, and northwest-southeast. All three orientations can be identified in seismic data. A few basin fractures offset bedding in a normal sense, consistent with the seismic-scale normal faulting. Resistivity of the fractures varies but includes several wide aperture (10-30 $\mathrm{cm})$ and highly resistive (mineralized or cemented) fractures in the prism. Logging Unit III, at the basinprism transition, is characterized by increasing bedding dips and a fractured base. Borehole breakouts indicate a northeast-southwest oriented $S_{H \max }$, perpendicular to that at Site C0001. Breakout azimuth gradually rotates clockwise with depth and breakout width increases in the prism relative to the basin. Stress magnitude estimated from breakout width and empirical rock strength parameters is consistent with normal faulting in the basin, as observed, but are more ambiguous in the prism. Fracture and fault orientations, breakouts, and state of stress collectively support margin-normal extension of this part of the forearc. We suggest this is driven in part by uplift of the megasplay/outer-arc high causing gravitationally driven extension of the inner wedge. This contrasts with Site C0001 in the active outer prism, where convergence-related compression dominates.

\section{Log-seismic correlation}

The portion of the Kumano Basin drilled at Site C0002 includes a series of unconformity-bounded sequences. The shallowest is seismic Unit $2 / 3 / 4$ undifferentiated, which correlates closely with logging Unit I (Figs. F12, F13). The increase in velocity across this boundary is consistent with a transition from higher porosity sediments to older more compacted and perhaps sandier Kumano Basin stratigraphy. Seismic Unit 5 through uppermost seismic Unit 11 corresponds to logging Unit II.

Within logging Unit II there are two zones of interest. Zone A lies above the BSR ( 404 m LSF) and shows elevated resistivity and slightly increased velocities. Velocity and density decrease at the BSR, suggesting that the reflection may be generated by a contrast between sediments bearing free gas below and gas hydrate-bearing ones above. At the top of Zone $\mathrm{B}$, a strong, dipping negative polarity reflection within the seismic data correlates with a second region of low velocities. The regional observation that some reflectors brighten in amplitude as they approach the BSR from below, coupled with interpreted sandy turbidite layers based on gamma ray logs of Zone $B$, supports the suggestion that this reflection may represent sands bearing small amounts of free gas.

The top of the accretionary prism is a high-amplitude reflection and a clear boundary in all of the logs. A sequence of low gamma ray values just below the top of the prism suggest that a sandier interval may contribute to this bright reflection.

A complete check shot profile of 72 shots defined a clear velocity profile for the Kumano Basin stratigra- 
phy and drilled portion of the accretionary prism. This curve generally agrees well with the sonic log, with the exception of slightly lower velocities from 550 to $675 \mathrm{~m} \mathrm{LSF}$ and also agrees very well with the PSDM velocities.

\section{Site $\mathrm{C0003}$}

Site C0003 is located in the midslope region and targeted a major thrust fault of the megasplay fault system, as well as the overlying thrust sheet and underlying footwall to the thrust (Fig. F14). Drilling at this site was designed to begin the downdip transect of the megasplay fault system by sampling a relatively shallow, presumably aseismogenic point on the fault zone at $\sim 800$ mbsf. The objectives of taking logging data from this site were to characterize the material properties, deformational features, and conditions in the fault zones, wall rocks, and sediments. Unfortunately, poor drilling conditions in the highly unstable thrust sheet only permitted us to penetrate to $525.5 \mathrm{~m} \mathrm{LSF}$ at this site before the drill string became irretrievably stuck and the BHA was lost in the hole and ultimately cemented in place. The MWD-transmitted real-time data from the LWD tools and rig floor parameters are the only available data sets from this site. Fortunately, these real-time data are of sufficient quality that we were still able to obtain a great deal of useful information from the interval 0-525.5 m LSF.

\section{Log characterization and lithologic interpretation}

Three broad units were defined for the interval of relatively good quality real-time data available ( 55$509 \mathrm{~m}$ LSF). Logging Unit I (55-76.6 m LSF) is interpreted as muddy to sandy slope basin sediments, exhibiting moderately high gamma ray baseline values and fairly constant resistivity values (Fig. F15). Logging Unit II (76.6-151.5 m LSF) is characterized by a large degree of hole washout and low gamma ray values. This suggests a formation dominated by unconsolidated and porous sandy beds. Based on seismic reflection data, it is interpreted as a deformed part of the thrust sheet. Logging Unit III (151.5-509 m LSF) exhibits a broad increasing gamma ray trend with fairly constant resistivity and density values. Logging Unit III contains several zones of apparent deformation characterized by changes in the resistivity and density. Overall, logging Unit III is interpreted as clay-rich sediments showing no significant compaction trend with depth, as part of the thrust sheet of the megasplay fault branch.

\section{Physical properties}

In Hole C0003A, some physical property measurements were significantly affected by hole conditions. For example, where severe washouts were detected, density decreased and neutron porosity increased dramatically and therefore these measurements are not reliable (Fig. F15). Even ring resistivity is affected in logging Unit II; however, bit resistivity seems to remain relatively unaffected. In the major washout zone between $\sim 400$ and $\sim 450 \mathrm{~m} \mathrm{LSF}$, density and porosity (both neutron and density-derived porosity) are significantly affected by hole conditions but no notable decrease in resistivity was found. This could be explained by worsening hole conditions between the time of the resistivity and density/porosity measurements; the latter are recorded later because of the position of the tools in the BHA. The pronounced occurrence of enlarged borehole, despite lack of evidence for sandy sediment, may suggest that this is a zone of caving of brecciated rock, perhaps from a fault zone.

\section{Structural geology and geomechanics}

Because of the lack of image data and the poor quality of the density and sonic logs (Fig. F15), we derived structural interpretations from the caliper, gamma ray, and resistivity logs. A number of washouts or caving zones (high-caliper intervals) occur in logging Unit III. Because the gamma ray and resistivity logs do not decrease through these intervals they probably represent poorly consolidated argillaceous material, or most likely, fault breccia. Three prominent washout zones occur between 416 and $451 \mathrm{~m}$ LSF, with several others within tens of meters above and below this interval. This area of the borehole also corresponds to bright tilted reflectors, further strengthening the interpretation of these washout zones as intervals of caving of brecciated rock from faults within the hanging wall thrust sheet of the major fault that was the target of drilling.

\section{Log-seismic correlation}

Logging Unit I corresponds to the slope basin, and the logging Unit I/II contact is likely the positive polarity reflection separating the base of the slope basin and top of the wedge-shaped upper thrust sheet sequence (Figs. F14, F15). The logging Unit II/III contact is the negative polarity reflection at the base of the wedge-shaped sequence. Logging Unit III spans the low-reflectivity sequence including the fault zone to the total depth (TD) of $525.5 \mathrm{~m}$ LSF. The reflection separating the slope basin sediments from 
the wedge-shaped sequence is positive polarity; however, the density log decreases sharply across this boundary. We suggest that washouts in sandy Unit II decreased the density values measured in this unit. The combination of a sand-rich Unit II with higher densities and a low-density interval $\sim 3 \mathrm{~m}$ below the base of the Unit II/III boundary may explain the negative polarity reflection. Fault-related reflections in logging Unit III can be associated with washout zones or damaged zone associated with the faults.

We used real-time check shot data from 10 stations ranging in depth from 86 to $506 \mathrm{~m}$ LSF. The first arrival waveforms from these stations are of high quality. The data were used to obtain long wavelength interval velocities in the hole and to correct the PSDM seismic section. Because good-quality $P$-wave velocity data are not available, we calculated synthetic seismograms using interval velocities from check shot data and real-time density data. The density data used for the synthetic seismogram are modified in logging Unit II because of the low reliability in this interval. The synthetic seismogram can be basically correlated with the major features of PSDM seismic section, but we cannot exactly fit the synthetic seismogram to the PSDM section in some intervals, probably because of the low overall quality of the limited data set available for this purpose.

When the broken section of drill pipe was recovered to the rig floor, it was plugged with cuttings and numerous large blocks (as large as $5-8 \mathrm{~cm}$ in diameter) of cavings that had come from an unknown position in the hole. This material had a nannofossil age of late Miocene (5.5-7.2 Ma). It is remarkably well indurated for material from $<530$ mbsf. This is consistent with the thrust sheet having been uplifted from older parts of the accretionary complex.

In summary, the portion of the thrust sheet penetrated at Site C0003 was a largely homogeneous material, most likely silty to clayey hemipelagic muds and turbidites, clearly heavily deformed by multiple faults and associated brittle fractures.

\section{Site $\mathbf{C 0 0 0 4}$}

As an alternative to Site $\mathrm{COO03,} \mathrm{which} \mathrm{was} \mathrm{unsuc-}$ cessful in reaching the megasplay primary target, Site C0004 (proposed Site NT2-01I) was drilled at a location where the megasplay was predicted to lie at only 280 mbsf (Figs. F16, F17). To test drilling conditions prior to risking the LWD-MWD tool string, pilot Hole C0004A was drilled without any of the LWD-MWD tools to the planned TD of $400 \mathrm{mbsf}$, and then Hole C0004B was drilled with the full LWD tool string except the nuclear components of the adnVISION tool (neutron porosity/density). Drilling was smooth and reached TD quickly, and data quality was good, particularly for sonic velocity.

\section{Log characterization and lithologic interpretation}

Three logging units were defined based on the different trends and character of the LWD log responses (Fig. F18). Logging Unit I (0-67.9 m LSF) is characterized by variable gamma ray values and low resistivity and is interpreted as slope basin deposits. Logging Unit II (67.9-323.8 $\mathrm{m} \mathrm{LSF}$ ) was defined for the thrust sheet and associated complexes and divided into four subunits. Logging Subunit IIA is characterized by increasing gamma ray value, increasing resistivity baselines, and increasing velocity and is interpreted as chaotic or deformed sediments, possibly emplaced through gravitational processes (slumping). Logging Subunit IIB is characterized by continuous high-frequency fluctuation in gamma ray value, constant resistivity baseline, and increasing velocity. Logging Subunit IIC is characterized by cyclic changes in gamma ray value, variable resistivity, and again increasing velocity. Logging Subunit IID is characterized by decreasing gamma ray value and repeated intervals of decreasing resistivity and velocity. The upper part of this subunit is strongly deformed and the lower part is weakly deformed. The base of logging Unit II is interpreted as a weakly localized deformation zone. Logging Unit III (323.8 m LSF to TD) is characterized by decreasing gamma ray value, variable resistivity, and relatively constant sonic velocity and is interpreted as sediments underthrust beneath the splay fault.

\section{Physical properties}

Given the lack of a neutron log, porosity and density were estimated using five different resistivity logs (ring; bit; and deep, medium, and shallow button) and the sonic velocity obtained from the traveltime (DTCO) measurements (Fig. F18). No radioactive source was used at Site C0004, and accordingly neither the neutron porosity nor bulk density logs were available. Analyzed physical properties were compared with identified fracture zones (see "Structural geology and geomechanics"). Shallow button resistivity is significantly lower than the other two button readings, most likely a sign of generally enlarged hole conditions seen in caliper data. Estimated porosity, calculated from bit and ring resistivity corrected with the estimated temperature profile, shows 
a slowly decreasing trend with depth below the slope cover. The sonic $P$-wave velocity log is of good quality and its response appears to reflect the effects of fracture zones and logging units, identifiable as lowvelocity zones.

\section{Structural geology and geomechanics}

Three structural domains were defined by structural characteristics, including fractures, breakouts, and texture in the borehole images. Structural Domain 1 (0-96 m LSF) is characterized by a lack of fractures, weak breakouts, and little variation in the sediments (Fig. F18). Structural Domain 2 (96-292 m LSF) includes heavily or moderately fractured conductive zones and intensive borehole breakouts. Structural Domain 3 (292-396 m LSF) has few fractures and narrower breakouts relative to the overlying domains. Bedding planes in structural Domain 1 are consistent and mostly strike northeast-southwest and $\operatorname{dip} 30^{\circ}-40^{\circ}$ to the south. The beds in structural Domain 2 are more scattered both in dip and azimuth but generally trend northeast-southwest and dip at $20^{\circ}-70^{\circ}$ to the north. Structural Domain 3 shows similar bedding strike as Domain 2 (northeast-southwest) but the dips are generally gentler to the north. Most fractures we identified are conductive and only found in Domains 2 and 3. Fractures in structural Domain 2 are scattered both in strike and dip but with a dominant strike of northeast-southwest, steeply dipping to the north. Fractures in structural Domain 3 show northeast-southwest strike and gentler dip $\left(10^{\circ}-20^{\circ}\right)$ to the north. Fractured zones were defined by intense development of fractures and wide conductive breakouts and were classified as "major" or "minor." In structural Domain 2, three major fractured zones and four minor fractured zones are identified, whereas structural Domain 3 includes only a minor fractured zone.

Borehole breakouts indicate a consistent northwestsoutheast oriented $S_{\mathrm{H} \max }$ axis throughout the borehole, which is between the $S_{\mathrm{H} \max }$ direction at Site C0001 and the convergence direction. Breakout width is narrow in Domain 1, wide in Domain 2, and slightly reduced again in Domain 3. Stress magnitude was analyzed from breakout widths, but stress regime is unclear because of uncertainty in rock strength. Domain 1 consists of logging Units I and IIA, which could be interpreted as two sedimentation stages of slope deposits because of small changes in physical properties. Deformation characteristics at the boundary of structural Domains 2 and 3 suggest a narrow (few meters) transition zone between the hanging wall and footwall of the main thrust. Structural features identified in borehole im- ages, bedding, and fractured zones are well correlated with the structural style in the reflection seismic profiles and are compatible with convergence related deformation.

\section{Log-seismic correlation}

The base of the slope sediment section corresponds to the logging Unit I/II boundary (Figs. F16, F18). Sonic velocity increases at the boundary from little more than drilling fluid velocity to about $1600 \mathrm{~m} / \mathrm{s}$. There are similar increases in the gamma ray and resistivity logs. The transition in each of the logs is gradual rather than abrupt. These gradual changes likely account for the relatively low frequency character of the reflection at the base of the slope basin sediments.

Logging Subunit IID corresponds to a thick zone of roughly parallel northwest-dipping reflections interpreted as the signature of a system of faults along which accretionary prism rocks have been thrust over slope basin sediments. Seismic reflections on both the inline and cross-line adjacent to the hole show considerable variation on a scale of $50-100 \mathrm{~m}$. Thus, we do not expect an exact correlation between log values in a single hole and the seismic data that smear the image laterally on a scale of $20-40 \mathrm{~m}$, and it was in fact difficult to correlate the depth of the apparent fault zones in logs to reflector position.

Velocity in the upper half of the dipping reflection package decreases from $\sim 1900$ to $\sim 1800 \mathrm{~m} / \mathrm{s}$ from 243 to $291 \mathrm{~m}$ LSF. The sonic log begins a significant increase in interval velocity, from $\sim 1900$ to $2100 \mathrm{~m} / \mathrm{s}$ at $291 \mathrm{~m}$ LSF. Velocity remains high to $\sim 313 \mathrm{~m} \mathrm{LSF}$ before dropping back to $\sim 2000 \mathrm{~m} / \mathrm{s}$. This high velocity corresponds to the base of the broad trough and the top of the basal peak of the dipping reflection section. There is a thin layer with dramatically lower velocity at $\sim 306 \mathrm{~m} \mathrm{LSF}$ that is within the basal bright peak of the dipping sequence. The nearly flat horizons below have velocities varying between 2000 and $2100 \mathrm{~m} / \mathrm{s}$ and form a series of bright peaks and troughs.

Usable check shot data were acquired at 21 depths in Hole C0004B that provided reasonable velocity information. Beyond the general increase of interval velocity from $1500 \mathrm{~m} / \mathrm{s}$ at the seafloor to $2100 \mathrm{~m} / \mathrm{s}$ at $400 \mathrm{~m}$, there is not an exact match between the check shot velocity curve and the sonic log values.

\section{Site $\mathrm{CO005}$}

Site C0005 was drilled without any logging tools. No measurements were made after failure to reach TD in the first pilot Hole C0005A (proposed Site NT2-01E) 
because of poor hole condition and in the second pilot Hole C0005B (proposed Site NT2-01G) because of ROV problems right at the beginning of drilling (Fig. F17). Site C0005 was then abandoned for lack of time in favor of higher priority objectives at Site c0006.

\section{Site $\mathrm{C0006}$}

Site C0006 is located at the frontal thrust of the Nankai accretionary prism near the trench axis, and drilling targeted the main frontal thrust at $\sim 700 \mathrm{mbsf}$, subsidiary faults and deformed sediments above that zone, and a footwall zone of strong reflectors likely caused by coarse turbiditic trench fill sediments (Fig. F19). Overall objectives of drilling this site with LWD-MWD instruments were to characterize the lithology, deformation, stress state, and physical properties of the wall rocks and the frontal thrust fault zone. Pilot Hole C0006A was drilled with a MWDAPWD and gamma ray tool string to a TD of $885.5 \mathrm{~m}$ LSF, and Hole C0006B was drilled to the same TD with the full LWD tool string but without any radioactive source in the adnVISION tool. Because the water depth was beyond the ROV limit of 3000 meters below sea level, both holes were drilled without ROV monitoring. Drilling was smooth; however, real-time MWD communication was lost in Hole C0006 at 274 mbsf, as well as power from the MWD turbine. The LWD tools recorded data in memory mode on battery power; however, the sonic source transducers were negatively affected and sonic data were of very poor to unusable quality from $274 \mathrm{~m} \mathrm{LSF}$ to TD (885.5 m LSF).

\section{Log characterization and lithologic interpretation}

Four logging units were defined based on the different trends and character of the LWD log responses (Fig. F20). Logging Unit I (0-197.8 m LSF) is characterized by variable gamma ray values and high-amplitude fluctuation of resistivity and is interpreted as sandy and muddy deposits. Logging Unit II (197.8$428.3 \mathrm{~m} \mathrm{LSF}$ ) is characterized by a gradually increasing trend in the gamma ray log with occasional thick $(5 \mathrm{~m})$ low-gamma layers. This unit is interpreted as mudstone with thick sandstone beds. Possible repeated stratigraphic sections are recognized in this logging unit. Logging Unit III (428.3-711.5 m LSF) was defined based on inferred alternating beds of mudstone and sandstone and divided into two logging subunits. Logging Subunit IIIA is characterized by high gamma ray values with thin $(1 \mathrm{~m})$ low gamma ray layers. Logging Subunit IIIB is characterized by high gamma ray values with a large number of thin $(1 \mathrm{~m})$ low gamma ray layers and repeated increasing trends in resistivity. The base of logging Unit III is interpreted as both a fault zone as well as a distinct lithologic boundary. Logging Unit IV (711.5 $\mathrm{m}$ LSF to TD) is characterized by low gamma ray value and resistivity and interpreted as being composed of abundant sandstones.

\section{Physical properties}

Porosity and density were estimated using five different resistivity logs (ring; bit; and deep, medium, and shallow button) and the sonic velocity obtained from DTCO measurements (Fig. F20). No radioactive source was used in Site C0006, and accordingly neither the neutron porosity nor density logs were available. The deep and medium button resistivity logs show very good agreement. Shallow button resistivity is significantly lower than the other two button logs in logging Units I and IV. Estimated porosity, calculated from bit and ring resistivity using the estimated temperature profile, shows a slowly decreasing trend with depth from 0 to $\sim 650 \mathrm{~m}$ LSF and shows increasing trend with depth below $650 \mathrm{~m}$ LSF. Because of the malfunction of the sonic tool, $P$-wave velocity data were only measured to $\sim 160 \mathrm{~m}$ LSF. Velocity appears to be nearly constant or slightly increasing over this shallow interval. Velocity and resistivity are generally in good agreement, and high velocity zones correspond to high resistivity zones.

\section{Structural geology and geomechanics}

Good quality borehole resistivity images provide information on orientation of bedding, fractures, and breakouts at Site C0006 (Fig. F20). Bedding dips are shallow to moderate with most dips $<30^{\circ}$. The mean bedding dip is west-northwest in shallow parts of the hole and more northerly dips are formed in logging Units III and IV. Fractures at Site C0006 are notably not as clustered into zones as at other Expedition 314 sites. Fractures strike mostly northeastsouthwest in the upper two lithologic units (above $428 \mathrm{~m}$ LSF). Fractures in the deeper two lithologic units (429-853 m LSF). Overall bedding and fracture orientations at depths below $429 \mathrm{~m}$ LSF (logging Units III and IV) are consistent with northwesterly directed shortening. In general, deformation at Site C0006 is weaker than at other active prism sites, with less fracturing and no major deformation zones.

Borehole breakouts occur from 188 to 729 m LSF but are in general much more weakly developed than at other sites drilled during this expedition. Breakouts are not readily discernible at greater depths. The lack of discernible breakouts below 729 m LSF occurs just 
below the transition to lithologic Unit IV, which is dominated by sand, where conductive washouts may obscure breakout evidence. Breakouts show a mean $S_{\text {Hmax }}$ orientation of $330^{\circ}$, consistent with that observed at Sites C0001 and C0004 but divergent from the $S_{\text {Hmax }}$ expected from the far-field convergence of the Philippine Sea plate and Japan.

\section{Log characterization and lithologic interpretation}

Logging units do not correlate well with seismic reflection data, probably because the section is strongly faulted. Several faults that intersect the well location are visible on the seismic data (Fig. F20). Several features in the LWD logs do, however, correlate with features on the seismic data. For example, the sandy layers (low gamma ray values and resistivity) at $\sim 220,240,300$, and $335 \mathrm{~m}$ LSF correlate with strong reflections and appear to be parts of the same unit that have been repeated as a result of thrusting (Fig. F20). Several seismically defined thrust faults also correlate with features in the resistivity images, such as the conductive fractures at 360 and $381 \mathrm{~m}$ LSF. The basal décollement correlates with a fracture at $657 \mathrm{~m} \mathrm{LSF}$.

\section{Summary and implications}

Together with coring during Expeditions 315 and 316, the objectives of Expedition 314 were to drill a transect of riserless sites that would characterize the lithologies, physical and mechanical properties, structures, and stress conditions in the sediments at relatively shallow depths below seafloor on the Nankai margin and establish the riserless "top-hole" conditions and properties at the two sites slated for deep riser drilling in later stages of NanTroSEIZE drilling. Our specific goal on Expedition 314 was to obtain the maximum possible in situ data by logging in dedicated LWD holes, with Expeditions 315 and 316 slated to core twinned holes at each of the sites we logged. Our targets were the accretionary prism and faults therein and the major forearc basin overlying the hypothesized seismogenic zone. To this end, we drilled and logged (Fig. F8; Table T1) from 0 to 885.5 mbsf at the frontal thrust site at the toe of the entire accretionary prism (Site C0006), 0 to 400 mbsf across the out-of-sequence megasplay fault system (Site C0004), 0 to 1000 mbsf into the thrust sheet above the megasplay in a pilot hole for future riser drilling (Site C0001), and 0 to $532 \mathrm{mbsf}$ at a second site in that thrust sheet (Site C0003), and 0 to $1401 \mathrm{mbsf}$ at a site crossing $976 \mathrm{~m}$ of the Kumano forearc basin and $425 \mathrm{~m}$ of the underlying older accretionary prism rocks (Site C0002), completing the pilot hole for a second future riser drilling effort.

At these sites, we conducted an extensive suite of LWD logging, including gamma ray values, resistivity imaging, sonic velocity, neutron porosity, lithodensity, and check shot seismic. This body of data is collectively the most advanced LWD data recorded in scientific ocean drilling to date and is also the largest number of meters logged with LWD during a single expedition in IODP or ODP. Hole C0002B is the deepest penetration into an accretionary prism and the deepest LWD hole ever in scientific ocean drilling.

Not all sites have all logs available. In some cases equipment malfunctions caused loss of some logging data (e.g., sonic log at Site C0006), and after the loss of the LWD BHA at Site C0003, we were unable to record porosity or density data at the subsequent sites because of the lack of a radioactive source.

\section{Key results}

\section{Lithology and structure of faults and thrust sheets}

As expected, we found that logs are consistent in showing sediments dominated by hemipelagic muds/mudstones and turbidites, with relatively little sand except at the trench site (C0006) and in the slope basin deposits (Fig. F21). In the absence of cores, our main tool for structural analysis of deformed zones, fractures and faults, bedding attitude, and borehole stress was resistivity imaging. We documented bedding attitudes consistent with the seismic interpretation of structural domains: relatively shallow bedding in basinal settings with well-imaged, continuous reflectors and more variable and steeper dips in areas imaged as strongly deformed thrust sheets, accretionary mélange, and apparent fault zones. The thrust sheet drilled in the hanging wall of the megasplay fault at Sites C0001 and C0004 is a strongly deformed zone and has bedding attitudes clearly differentiated from the slope basin sediments that overlie and also the strata that underthrust the fault. Similarly, the Kumano forearc basin section at Site C0002 exhibits gentle dip, in close agreement with the seismic reflection interpretations, whereas the underlying "basement," interpreted as older accreted sedimentary rocks, shows highly variable bedding orientation. Rocks of that underlying prism and of the thrust sheet below 500 $\mathrm{m}$ LSF at Site C0001 are anomalously dense with high sonic/seismic velocity for their burial depth, indicating more advanced lithification. In the case of Sites C0001 and C0004, this suggests significant uplift and exhumation along the splay thrust, though 
that hypothesis must be confirmed with core data. At Site C0006, the frontal thrust region, the bedding is less variable in general, in agreement with the incipient nature of the deformation at this site, and dips are generally shallow. Physical properties are consistent with shallowly buried sediments that have been only weakly lithified at this site.

\section{Borehole breakouts and stress}

Borehole breakouts were observed at all four sites for which we have imaging data and show very systematic orientations (see below) (Fig. F22). In a vertical borehole, the orientation of breakouts is a well-established indicator of the orientation of the horizontal maximum principal stress in the present-day stress field (Zoback et al., 2003). Less frequently, drillinginduced tensile fractures were observed, primarily at Site C0001 in the splay fault thrust sheet. Breakout orientations at Sites C0001, C0004, and C0006 all indicate northwest-southeast azimuths of the maximum horizontal principal stress $\left(S_{\mathrm{H} \max }\right)$ (Fig. F23). In the thrust-dominated tectonic environment, this is consistent with trench-normal shortening, although strike-slip and/or normal faulting stress states are also permissible. Variations of the $S_{\text {Hmax }}$ direction among these three sites of as much as $10^{\circ}-20^{\circ}$ are statistically significant and may be due to local structure influencing local stress orientation. $S_{\mathrm{Hmax}}$ orientations deviate from the far-field plate motion vectors based on Global Positioning System results (Heki, 2007), implying strain partitioning between convergence and strike-slip motions.

At Site C0002 in the Kumano Basin, by contrast, the orientation of $S_{\text {Hmax }}$ is northeast-southwest, or nearperpendicular to that in the more trenchward sites. This is consistent with a normal faulting stress state which extends through the basin section (which exhibits normal faults) and also in the upper $400 \mathrm{~m}$, at least, of the underlying prism. This contrast suggests that the tectonic stress magnitudes differ greatly in the upper part of the prism at sites just a few kilometers apart along our transect and that gravitationally driven extension may be important above the megasplay where the outer arc high has been uplifted.

\section{Gas hydrates and bottom-simulating reflector}

At Site C0002, a well-developed BSR is imaged in the seismic data, and LWD logs recorded comprehensive in situ information about the nature of this BSR (see "Site C0002"). Resistivity logs showed a pattern of elevated resistivity background and spikes for $\sim 200$ $\mathrm{m}$ above the BSR depth at $\sim 400 \mathrm{~m}$ LSF (Fig. F24). The gamma response indicated that the spikes are in especially sandy intervals as thick as 1-2 $\mathrm{m}$, interpreted as the coarse basal beds in turbidite deposits.
Sonic and resistivity responses are consistent with pore space in these sands being partially filled and cemented with gas hydrate. In contrast, similar sands below the BSR depth show no elevated resistivity response. In a zone $80 \mathrm{~m}$ deeper and $\sim 70 \mathrm{~m}$ thick, a low resistivity response in the sandy beds suggests a potential gas-charged interval beneath the gas hydrate stability field. The logging data indicate that the BSR reflectivity is a response to both a small velocity high from hydrate cement in the hydrate stability zone and a more significant velocity low caused by the presence of uncemented sediments and/or free gas below the stability field. Ongoing further analysis will quantify the amount of pore space charged with hydrate in the zone above the BSR and, integrated with 3-D seismic analysis, the total amount of gas in this region of the Kumano Basin section.

Taken as a whole, the results of Expedition 314 LWD show that both the tectonic history and present-day stress conditions in the forearc basin region differ greatly from those in the outer accretionary prism thrust sheets and faults. This was manifested in both the logging and image data and in the difficult drilling conditions in the splay fault thrust sheet, where borehole caving and collapse was a near-constant risk. We tentatively conclude that this is an indication that the basic concept of the NanTroSEIZE transect-to span the lateral boundary between the aseismic outer accretionary prism and the seismogenic inner accretionary prism and forearc basin-is validated even by the LWD-based observations in the upper 400 to $1400 \mathrm{~m}$ LSF. In particular, one hypothesis to explain the apparent boundary in the state of stress between Sites C0001 and C0002 (only $10 \mathrm{~km}$ apart) is that these sites span the updip locked boundary zone. We hope that future deep riser drilling will test these inferences as we drill from the forearc basin region down to the actual plate interface fault system.

\section{Preliminary scientific assessment}

Expedition 314 is unique in Deep Sea Drilling Project/ODP/IODP history for two important reasons:

1. It was the first expedition of NanTroSEIZE, the first "Complex Drilling Project" in IODP, and therefore this expedition was explicitly seen as a part of a larger effort and not necessarily a standalone science program in its own right.

2. It was the maiden scientific voyage of a new drilling vessel, the Chikyu.

Based on the Scientific Prospectus (Kinoshita et al., 2007) our goal was to drill and log with the full suite of LWD-MWD tools a transect of six primary sites, 
including two on the incoming plate, two through major active thrust faults, and two to serve as pilots for deeper riser drilling while addressing scientific targets in the splay fault thrust sheet and the $\mathrm{Ku}$ mano forearc basin and underlying prism. The operational plan was structured very differently from previous ODP/IODP expeditions, with approximately one-third of the total 57 days allocated explicitly as undivided contingency time. We also used a logging system completely new to IODP (seismicVISION), as well as several systems that had rarely been used before (sonicVISION and adnVISION).

\section{Overall success}

We faced many challenges brought on by mechanical failure, very difficult natural drilling conditions, and our collective inexperience with the new organizational structure on board the Chikyu during Expedition 314. Nevertheless, we were able to drill and log successfully to full planned drilling depth (or at least to a depth sufficient to meet our objectives) at most of the planned sites. In particular, we consider the achievement of drilling the two future riser sites (C0001 and C0002) to full planned TD of 1000 and 1400 mbsf, respectively, to be a major achievement. We were able to drill across the potentially unstable frontal thrust zone and $\sim 130 \mathrm{~m}$ into the footwall at Site C0006 as planned. We were also able to successfully drill across the main splay fault zone at Site C0004, although this had to be done at a different, shallower depth (by several hundred meters) than originally planned after Site C0003 proved too unstable to successfully drill a borehole to the fault. We established in situ physical properties at sites in the thrust sheets, prism rocks, faults, and basin sediments; documented present-day stresses through borehole fractures and breakouts; and collected key data that will closely tie the 3-D seismic reflection volume to actual physical attributes of the rocks (especially when interpreted along with core data). The breakout stress information in particular directly addresses key objectives central to the NanTroSEIZE mission and is a major result of this expedition.

\section{Challenges}

Because of lost time from a variety of events, we were unable to attempt drilling at proposed Sites NT1-01 or NT1-07, the two reference sites on the incoming plate. The large amount of built-in contingency time was consumed in full by time lost to failure of mechanical systems, difficult drilling conditions including stuck pipe and a BHA with the LWD tools, and simple inexperience with estimating time needed to complete operations. The reference sites were important objectives, but their highest value objectives come through coring, not logging. We deemed these sites the least important to obtain LWD logs from, relative to the sites on the active accretionary prism/ plate boundary zone. Therefore, while regrettable, the inability to drill and log them during Expedition 314 is not a major setback to the program.

Unquestionably, two major unforeseen events were key in consuming the contingency time during the expedition. The first was the failure of the dynamic positioning system as we reached TD in Hole C0001D. Troubleshooting and fixing this problem occupied 7 days of operations time, during which no drilling could be done. The second was the lost BHA in Hole C0003A. Because the BHA included a complete set of the costly LWD tools and a radioactive neutron source, fishing for the stuck pipe was mandatory, though it proved unsuccessful in the end. This incident cost the expedition another 8 days. It also had repercussions for the rest of the expedition, as we had to use significant operational time to drill pilot holes, had no ability to use a radioactive source, and had to forego porosity/density data at our final two sites. Both of these downtime losses were not avoidable in our judgment, given the seriousness of the underlying incidents and the attention paid by the governmental agencies in Japan to loss of the radioactive source for safe and environmentally concerned operations.

The Kuroshio Current also presented a major challenge. Despite optimistic hopes, the current was present at all sites and more often than not ran at 3 kt or greater velocity. This made many different rig operations more difficult, from running drill pipe into the water to operating the ROV. The vortex-induced vibration (VIV) of the drill string when the current was flowing strongly caused shaking of the top drive and associated rig equipment, necessitating frequent maintenance as bolts were loosened. VIV also caused substantial downtime as the best mitigation for running into the hole in the current was to move the ship many kilometers upstream slowly, and then drift with the current while lowering pipe. ROV operations were also hampered by the current and, in several cases, damage to the ROV and its umbilical cable were caused by the strong current.

The difficult borehole conditions in this tectonically active faulting environment also caused substantial loss of operational time and failure of equipment. At several locations, Site C0005 in particular, pilot hole drilling or hole conditioning consumed substantial amounts of time that was then unavailable for LWD operations. Finally, the pioneering nature of this first expedition on the Chikyu meant that we had to work hard to establish basic routines for interaction between the Co-Chief Scientists, Expedition Project 
Manager, and Operations Superintendent and also for basic operational procedures onboard. Although we struggled with these issues in the early weeks of the expedition, we saw considerable improvements as time passed and experience was gained. With more experience on all sides, the organization of drilling and scientific activities on the Chikyu should proceed smoothly in the future.

In summary, considering all the challenges of pioneering a new operation in a very difficult drilling environment, Expedition 314 was remarkably successful and can be considered a very good start to the NanTroSEIZE project.

\section{References}

Ashi, J., Kuramoto, S., Morita, S., Tsunogai, U., Goto, S., Kojima, S., Okamoto, T., Ishimura, T., Ijiri, A., Toki, T., Kudo, S., Asai, S., and Utsumi, M., 2002. Structure and cold seep of the Nankai accretionary prism off Kumano-outline of the off Kumano survey during YK01-04 Leg 2 cruise. JAMSTEC J. Deep Sea Res., 20:1-8.

Austin, J.A., Jr., Christie-Blick, N., Malone, M.J., et al., 1998. Proc. ODP, Init. Repts., 174A: College Station, TX (Ocean Drilling Program). doi:10.2973/ odp.proc.ir.174a.1998

Binns, R.A., Barriga, F.J.A.S., Miller, D.J., et al., 2002. Proc. ODP, Init. Repts., 193: College Station, TX (Ocean Drilling Program). doi:10.2973/odp.proc.ir.193.2002

Flemings, P.B., Behrmann, J.H., John, C.M., and the Expedition 308 Scientists, 2006. Proc. IODP, 308: College Station, TX (Integrated Ocean Drilling Program Management International, Inc.). doi:10.2204/ iodp.proc.308.2006

Heki, K., 2007. Secular, transient and seasonal crustal movements in Japan from a dense GPS array: implication for plate dynamics in convergent boundaries. In Dixon, T., and Moore, C. (Eds.), The Seismogenic Zone of Subduction Thrust Faults: New York (Columbia Univ. Press), 512-539.

Ichinose, G.A., Thio, H.K., Somerville, P.G., Sato, T., and Ishii, T., 2003. Rupture process of the 1944 Tonakai earthquake $\left(M_{s} 8.1\right)$ from the inversion of teleseismic and regional seismograms. J. Geophys. Res., 108(B10):2497. doi:10.1029/2003JB002393

Kelemen, P.B., Kikawa, E., Miller, D.J., et al., 2004. Proc. ODP, Init. Repts., 209: College Station, TX (Ocean Drilling Program). doi:10.2973/odp.proc.ir.209.2004

Kimura, G., Silver, E.A., Blum, P., et al., 1997. Proc. ODP, Init. Repts., 170: College Station, TX (Ocean Drilling Program). doi:10.2973/odp.proc.ir.170.1997

Kinoshita, M., Goto, S., Hamamato, H., and Yamano, M., 2003. Heat flow distribution and thermal regime across the Nankai accretionary complex. Eos, Trans. Am. Geophys. Union, 84(46) (Suppl.):T42C-06 (Abstract).
Kinoshita, M., Moore, G., von Huene, R., Tobin, H., and Ranero, C.R., 2006. The Seismogenicic Zone Experiment. Oceanography, 19(4):28-38.

Kinoshita, M., Tobin, H., and Thu, M.K., 2007. NanTroSEIZE Stage 1: NanTroSEIZE LWD transect. IODP Sci. Prosp., 314. doi:10.2204/iodp.sp.314.2007

Kodaira, S., Takahashi, N., Park, J., Mochizuki, K., Shinohara, M., and Kimura, S., 2000. Western Nankai Trough seismogenic zone: results from a wide-angle ocean bottom seismic survey. J. Geophys. Res., 105:5887-5905.

Le Pichon, X., Iiyama, T., Chamley, H., Charvet, J., Faure, M., Fujimoto, H., Furuta, T., Ida, Y., Kagami, H., Lallemant, S., Leggett, J., Murata, A., Okada, H., Rangin, C., Renard, V., Taira, A., and Tokuyama, H., 1987a. Nankai Trough and the fossil Shikoku Ridge: results of Box 6 Kaiko survey. Earth Planet. Sci. Lett., 83:186-198. doi:10.1016/0012-821X(87)90065-3

Le Pichon, X., Iiyama, T., Chamley, H., Charvet, J., Faure, M., Fujimoto, H., Furuta, T., Ida, Y., Kagami, H., Lallemant, S., Leggett, J., Murata, A., Okada, H., Rangin, C., Renard, V., Taira, A., and Tokuyama, H., 1987b. The eastern and western ends of Nankai Trough: results of Box 5 and Box 7 Kaiko survey: Earth Planet. Sci. Lett., 83(1-4):199-213. doi:10.1016/0012-821X(87)90066-5

Mazzotti, S., Le Pichon, X., Henry, P., and Miyazaki, S.-I., 2000. Full interseismic locking of the Nankai and JapanWest Kuril subduction zones: an analysis of uniform elastic strain accumulation in Japan constrained by permanent GPS. J. Geophys. Res., 105(B6):13159-13178. doi:10.1029/2000JB900060

McNeill, L.C., Ienaga, M., Tobin, H., Saito, S., Goldberg, D., Moore, J.C., and Mikada, H., 2004. Deformation and in situ stress in the Nankai accretionary prism from resistivity-at-bit images, ODP Leg 196. Geophys. Res. Lett., 31(2):L02602. doi:10.1029/2003GL018799

Mikada, H., Becker, K., Moore, J.C., Klaus, A., et al., 2002. Proc. ODP, Init. Repts., 196: College Station, TX (Ocean Drilling Program). doi:10.2973/odp.proc.ir.196.2002

Miyazaki, S., and Heki, K., 2001. Crustal velocity field of southwest Japan: subduction and arc-arc collision. J. Geophys. Res., 106(B3):4305-4326. doi:10.1029/ 2000JB900312

Moore, G.F., Bangs, N.L., Taira, A., Kuramoto S., Pangborn, E., and Tobin H., 2007. Three-dimensional splay fault geometry and implications for Tsunami generation. Science., 318(5853):1128-1131. doi:10.1126/science.1147195

Moore, G.F., Mikada, H., Moore, J.C., Becker, K., and Taira, A. 2005. Legs 190 and 196 synthesis: deformation and fluid flow processes in the Nankai Trough accretionary prism. In Mikada, H., Moore, G.F., Taira, A., Becker, K., Moore, J.C., and Klaus, A. (Eds.), Proc. ODP, Sci. Results, 190/196: College Station, TX (Ocean Drilling Program), 1-25. doi:10.2973/odp.proc.sr.190196.201.2005

Moore, G.F., Taira, A., Klaus, A., Becker, L., Boeckel, B., Cragg, B.A., Dean, A., Fergusson, C.L., Henry, P., Hirano, S., Hisamitsu, T., Hunze, S., Kastner, M., Maltman, A.J., Morgan, J.K., Murakami, Y., Saffer, D.M., Sánchez- 
Gómez, M., Screaton, E.J., Smith, D.C., Spivack, A.J., Steurer, J., Tobin, H.J., Ujiie, K., Underwood, M.B., and Wilson, M., 2001. New insights into deformation and fluid flow processes in the Nankai Trough accretionary prism: results of Ocean Drilling Program Leg 190. Geochem., Geophys., Geosyst., 2(10). doi:10.1029/ $2001 G C 000166$

Moore, G.F., Taira, A., Klaus, A., et al., 2001. Proc. ODP, Init. Repts., 190: College Station, TX (Ocean Drilling Program). doi:10.2973/odp.proc.ir.190.2001

Moore, J.C., Klaus, A., et al., 1998. Proc. ODP, Init. Repts., 171A: College Station, TX (Ocean Drilling Program). doi:10.2973/odp.proc.ir.171A.1998

Nakanishi, A., Kodaira, S., Miura, S., Ito, A., Sato, T., Park, J.-O., Kido, Y., and Kaneda, Y., 2008. Detailed structural image around splay-fault branching in the Nankai subduction zone: results from a high-density ocean bottom seismic survey. J. Geophys. Res., 113:B03105. doi:10.1029/2007JB004974

Nakanishi, A., Takahashi, N., Park, J.-O., Miura, S., Kodaira, S., Kaneda, Y., Hirata, N., Iwasaki, T., and Nakamura, M., 2002. Crustal structure across the coseismic rupture zone of the 1944 Tonankai earthquake, the central Nankai Trough seismogenic zone. J. Geophys. Res., 107(B1):2007. doi:10.1029/2001JB000424

Obana, K., Kodaira, S., and Kaneda, Y., 2005. Seismicity in the incoming/subducting Philippine Sea plate off the Kii Peninsula, central Nankai Trough. J. Geophys. Res., 110:B11311. doi:10.1029/2004JB003487

O'Brien, P.E., Cooper, A.K., Richter, C., et al., 2001. Proc. ODP, Init. Repts., 188: College Station, TX (Ocean Drilling Program). doi:10.2973/odp.proc.ir.188.2001

Okino, K., Shimakawa, Y., and Nagaoka, S., 1994. Evolution of the Shikoku Basin. J. Geomagn. Geoelectr., 46:463-479.

Park, J.-O., Tsuru, T., Kodaira, S., Cummins, P.R., and Kaneda, Y., 2002. Splay fault branching along the Nankai subduction zone. Science, 297(5584):1157-1160. doi:10.1126/science.1074111

Riedel, M., Collett, T.S., Malone, M.J., and the Expedition 311 Scientists, 2006. Proc. IODP, 311: Washington, DC
(Integrated Ocean Drilling Program Management International, Inc.). doi:10.2204/iodp.proc.311.2006

Seno, T., Stein, S., and Gripp, A.E., 1993. A model for the motion of the Philippine Sea plate consistent with NUVEL-1 and geological data. J. Geophys. Res., 98:17941-17948.

Shipley, T.H., Ogawa, Y., Blum, P., et al., 1995. Proc. ODP, Init. Repts., 156: College Station, TX (Ocean Drilling Program). doi:10.2973/odp.proc.ir.156.1995

Taira, A., Hill, I., Firth, J.V., et al., 1991. Proc. ODP, Init. Repts., 131: College Station, TX (Ocean Drilling Program). doi:10.2973/odp.proc.ir.131.1991

Tobin, H.J., and Kinoshita, M., 2006a. Investigations of seismogenesis at the Nankai Trough, Japan. IODP Sci. Prosp., NanTroSEIZE Stage 1. doi:10.2204/ iodp.sp.nantroseize 1.2006

Tobin, H.J., and Kinoshita, M., 2006b. NanTroSEIZE: the IODP Nankai Trough seismogenic zone experiment. Sci. Drill., 2:23-27. doi:10.2204/iodp.sd.2.06.2006

Tréhu, A.M., Bohrmann, G., Rack, F.R., Torres, M.E., et al., 2003. Proc. ODP, Init. Repts., 204: College Station, TX (Ocean Drilling Program). doi:10.2973/ odp.proc.ir.204.2003

Wang, K., and Hu, Y., 2006. Accretionary prisms in subduction earthquake cycles: the theory of dynamic Coulomb wedge. J. Geophys. Res., 111(B6):B06410. doi:10.1029/ 2005JB004094

Wu, H.-Y., Ma, K.-F., Zoback, M., Boness, N., Ito, H., Hung, J.-H., and Hickman, S., 2007. Stress orientations of Taiwan Chelungpu-Fault Drilling Project (TCDP) hole-A as observed from geophysical logs. Geophys. Res. Lett., 34:L01303. doi:10.1029/2006GL028050

Zoback, M.D., Barton, C.A., Brudy, M., Castillo D.A., Finkbeiner, T., Grollimund, B.R., Moos D.B., Peska P., Ward, C.D., and Wiprut D.J., 2003. Determination of stress orientation and magnitude in deep wells. Intl. Jour. Rock Mech., 40(7-8):1049-1076. doi:10.1016/

j.ijrmms.2003.07.001

Publication: 11 March 2009

MS 314315316-111 
Figure F1. Location of sites drilled during Expedition 314 (red circles) in the Nankai Trough off Kumano, Japan. Black box $=$ location of the 2006 three-dimensional seismic survey, black line $=$ KR0108-5 two-dimensional seismic survey, yellow arrows $=$ computed far-field convergence vectors between Philippine Sea plate and Japan (Seno, 1993; Heki, 2007). Stars = epicentral location of great earthquakes. Inset shows location of Nankai Trough around the drill sites.

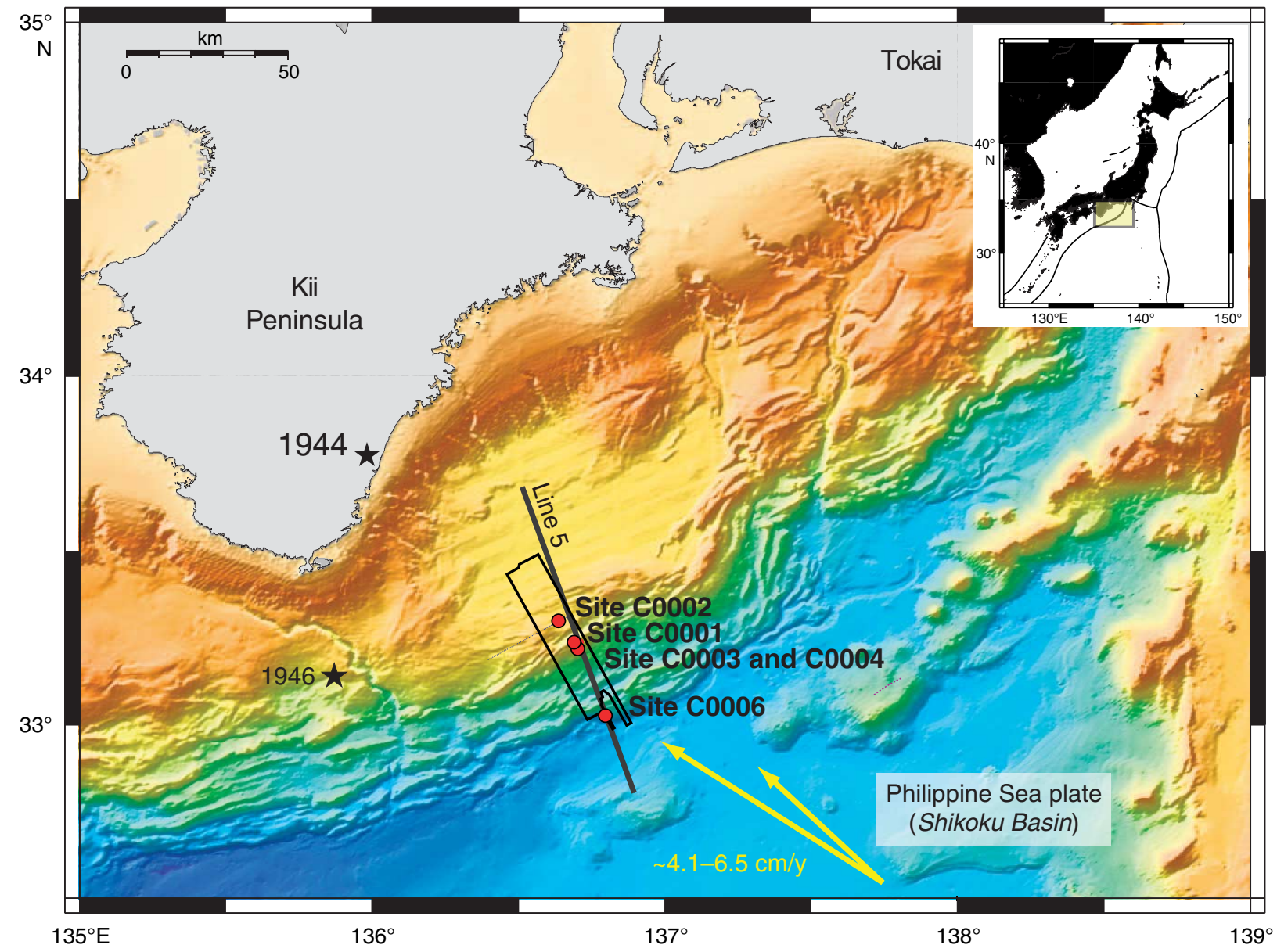


Figure F2. Kumano Basin region with Expedition 314 drill sites (red circles). Black box = location of the 2006 three-dimensional seismic survey, black line = KR0108-5 two-dimensional seismic survey, yellow arrows = computed far-field convergence vectors between Philippine Sea plate and Japan (Seno, 1993; Heki, 2007). Stars = epicentral location of great earthquakes. Gray shaded boxes = spatial distribution of slip (centimeters) during the 1944 Tonankai earthquake (Ichinose et al., 2003).

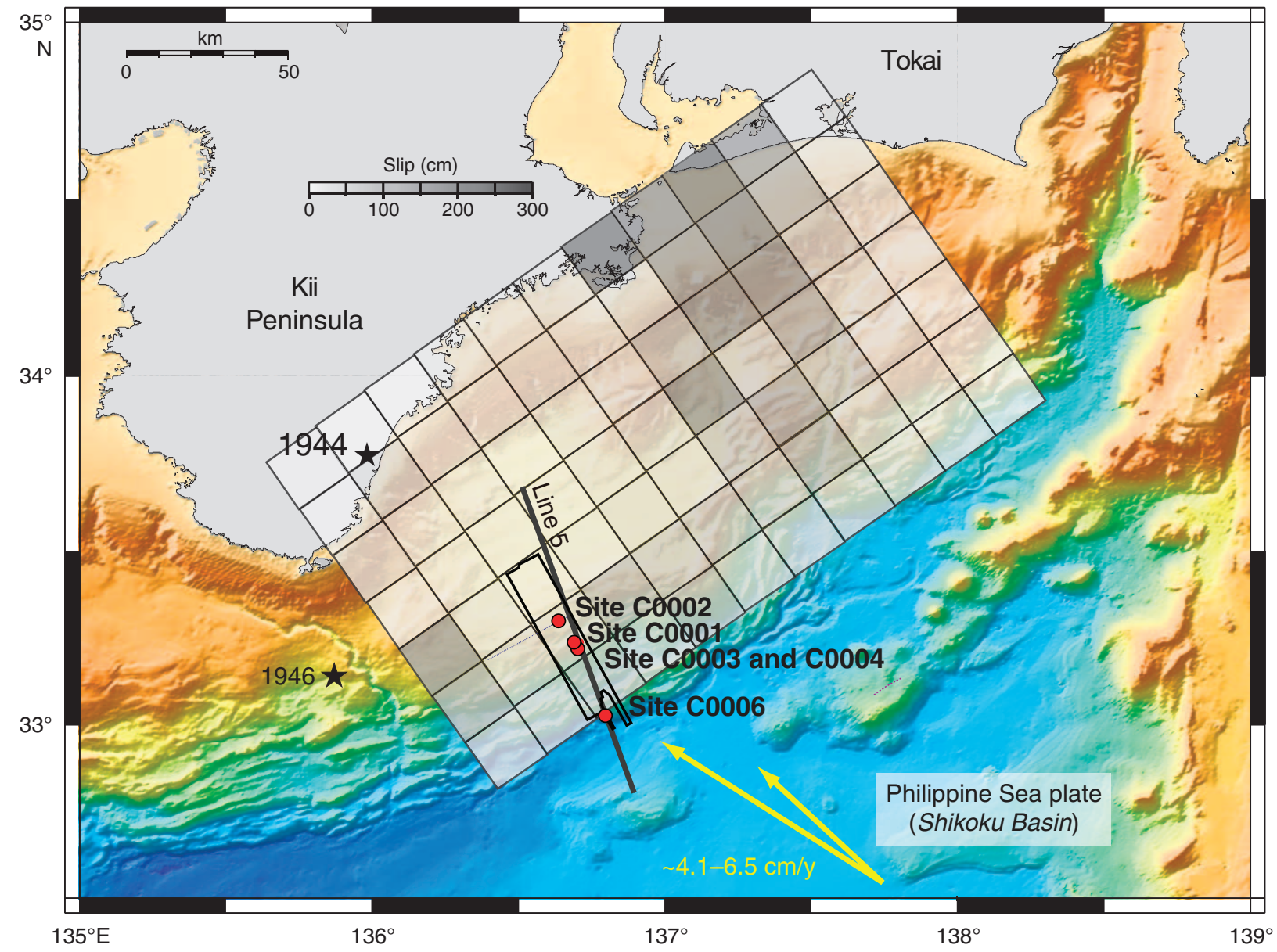


Figure F3. Location of LWD sites drilled during Expedition 314. Seismic section after Park et al. (2002). Solid color in holes = intervals drilled during Stage 1 , transparent color in holes = planned future drilling.

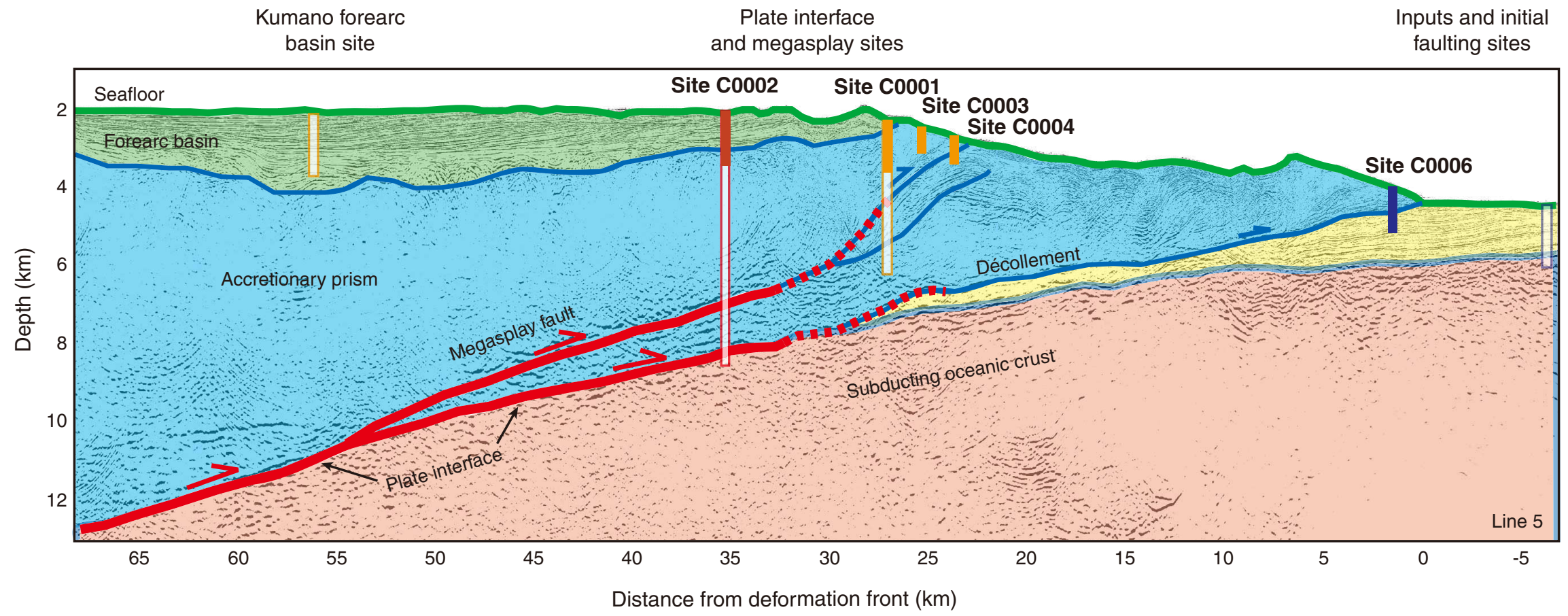


Figure F4. Location of sites drilled during Expedition 314 (black dots) overlain on SeaBeam bathymetry map.

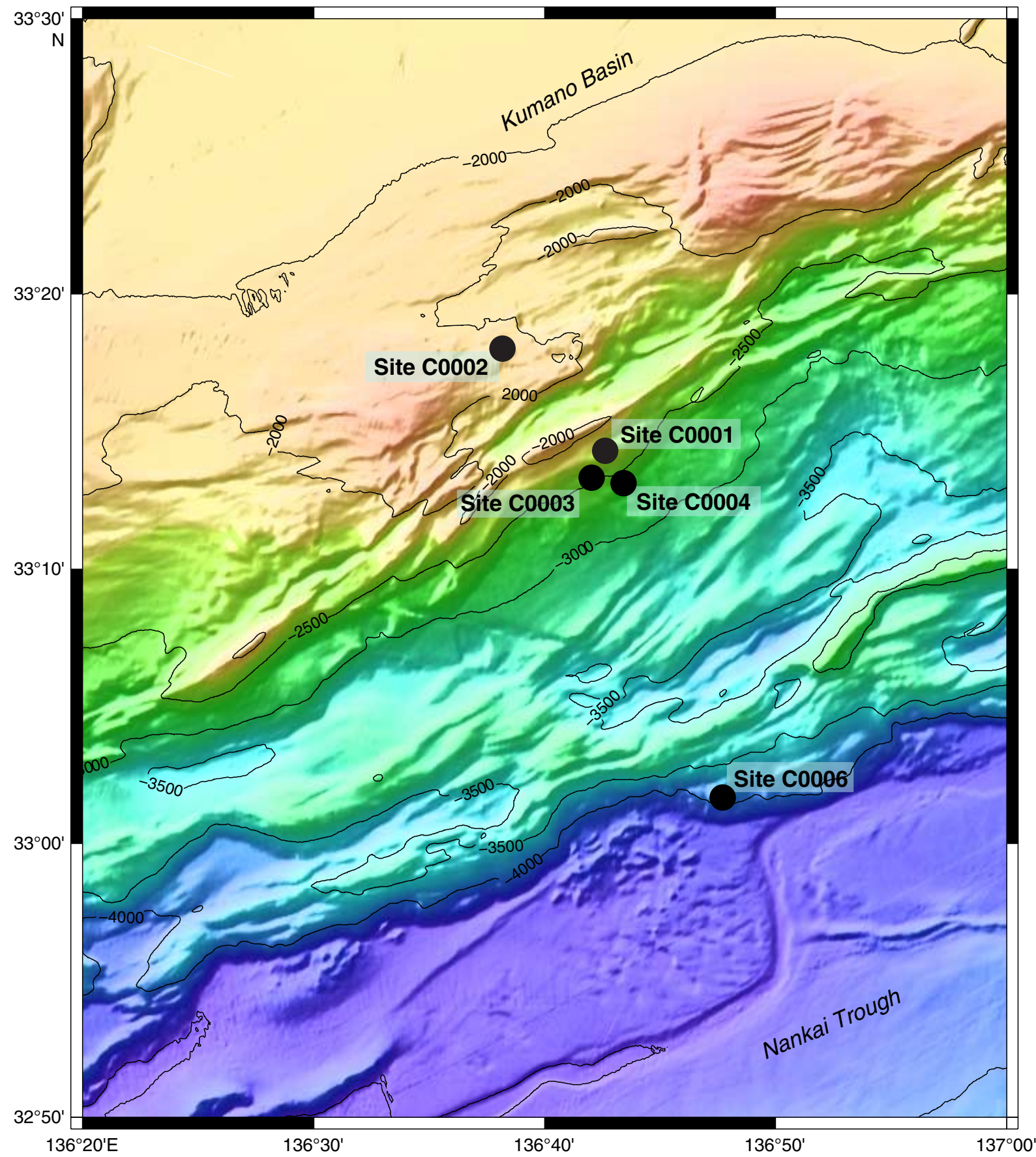


Figure F5. Drill string configuration used for MWD-APWD-LWD operations. OD = outer diameter, MWD = measurement while drilling.

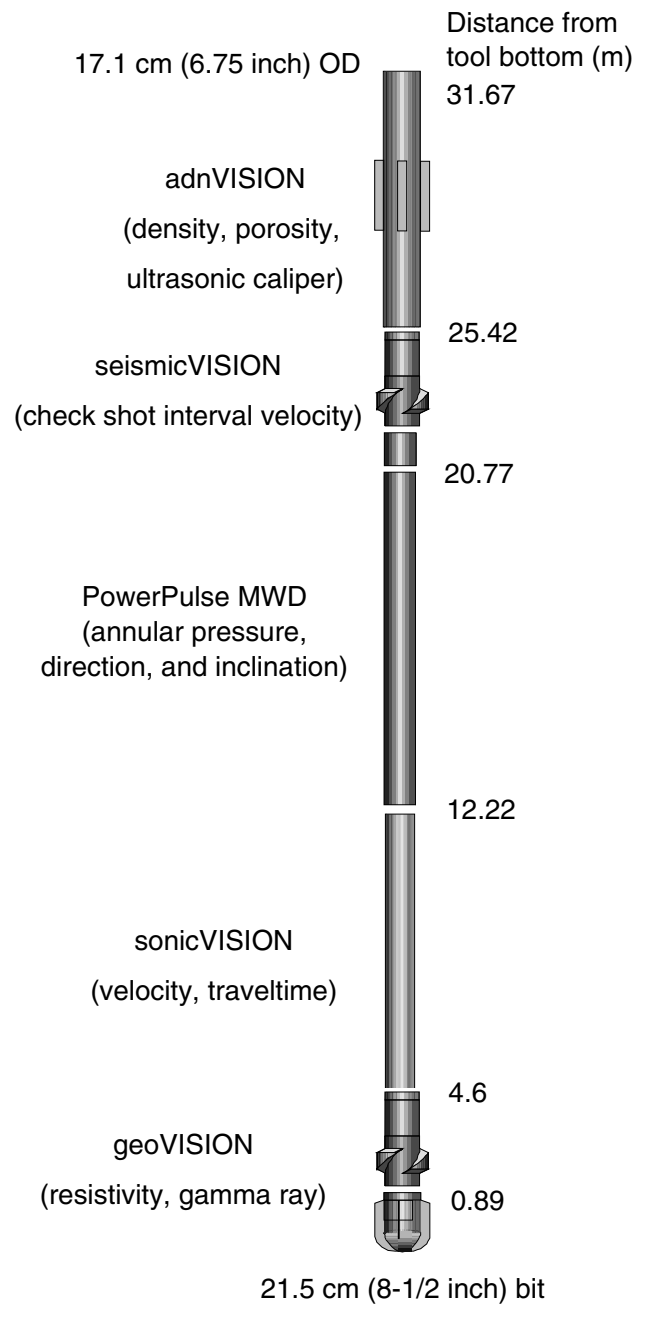


Figure F6. Interpreted three-dimensional seismic profile Inline 2645 across the Kumano forearc basin (Moore et al., 2007) showing four major unconformities (colored lines). $\mathrm{VE}=$ vertical exaggeration.

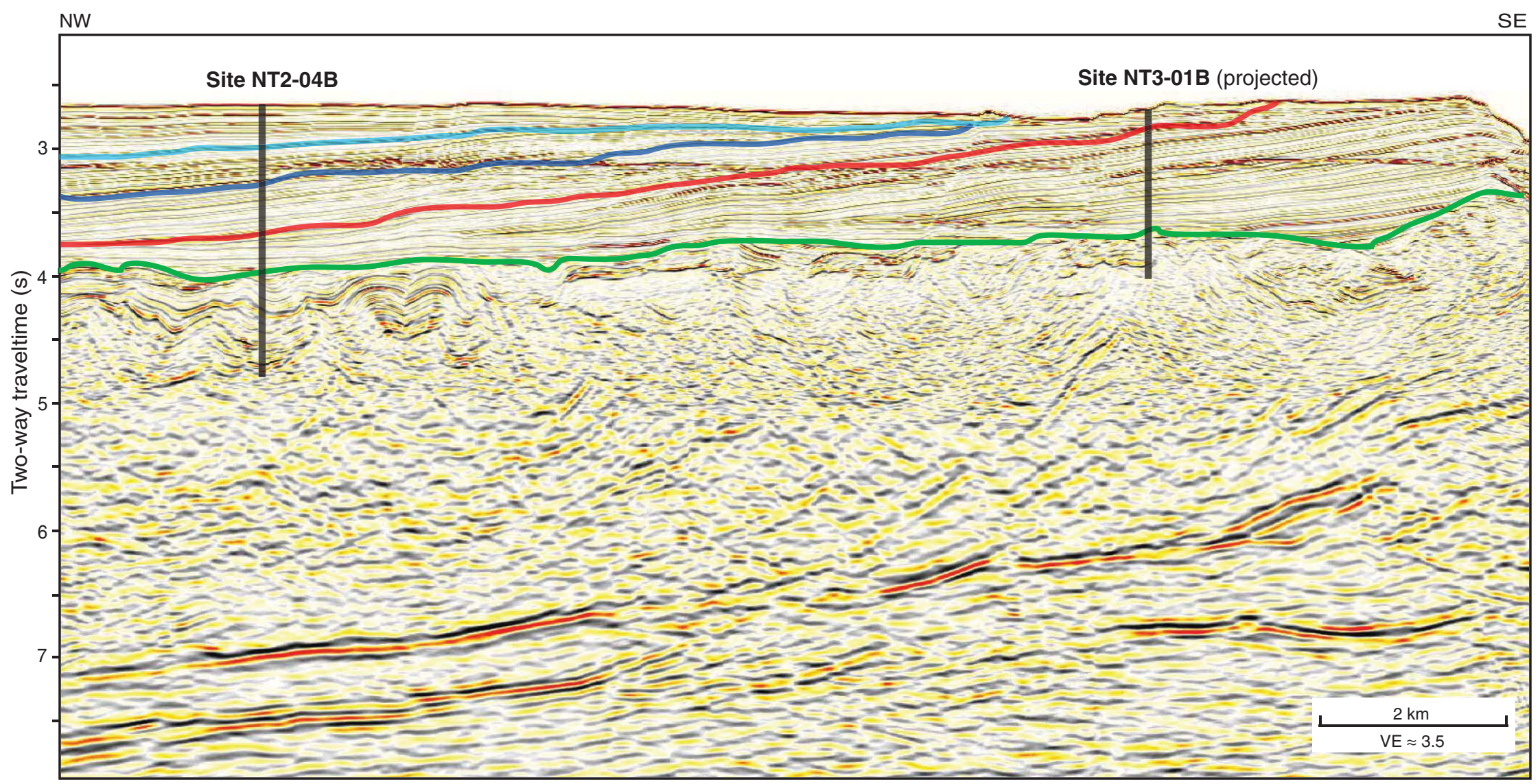


Figure F7. Locations of megasplay region LWD Sites C0001 and C0003-C0005 shown with three-dimensional seismic lines. IL = inline, $\mathrm{XL}=$ cross-line.

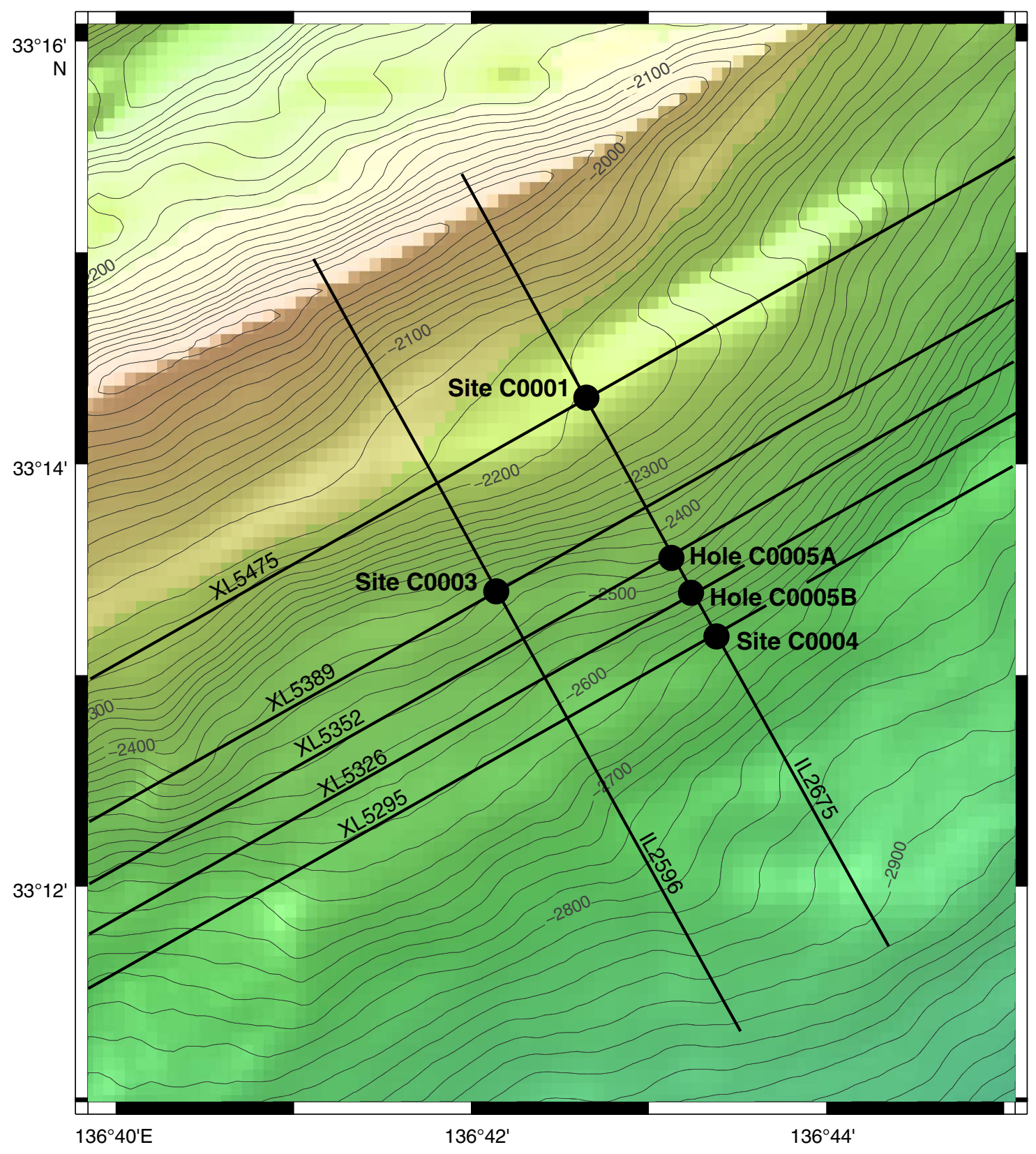


Figure F8. Depth section along an arbitrary line extracted from the three-dimensional seismic volume passing through the drilled sites (Moore et al., 2007). VE = vertical exaggeration.

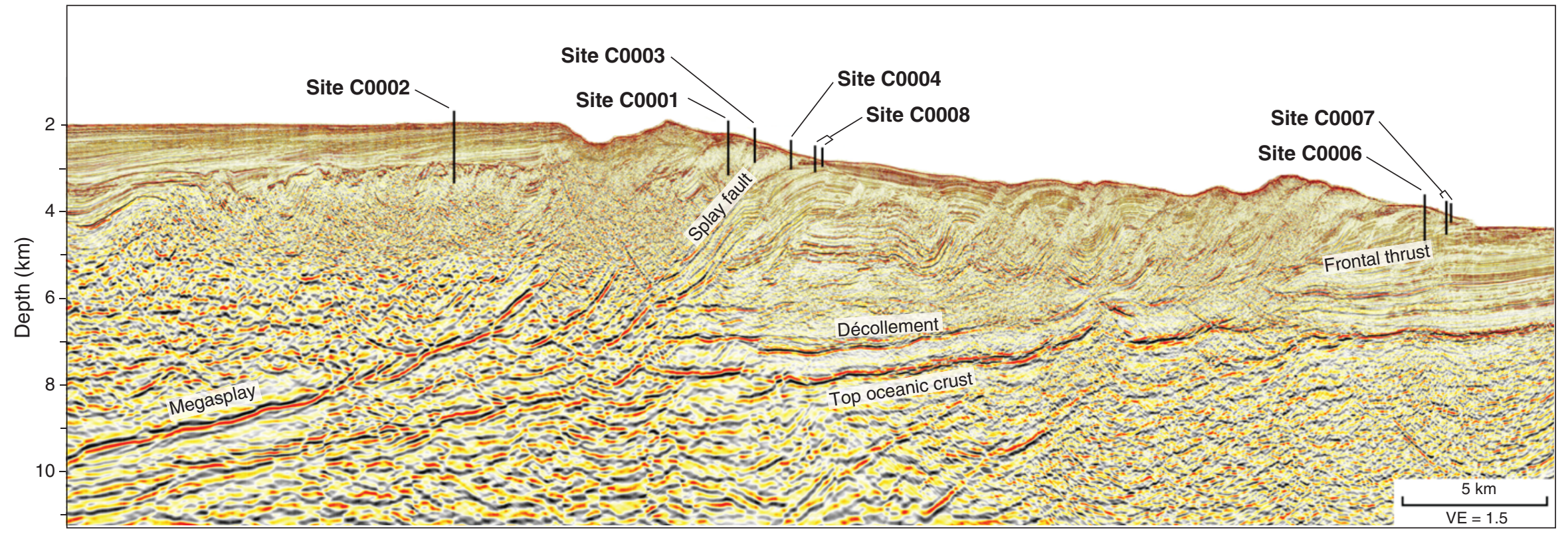


Figure F9. Three-dimensional seismic profiles crossing Site C0001 (Moore et al., 2007). Profile locations plotted in Figures F2 and F11. A. Inline 2675. B. Cross-line 5476. VE = vertical exaggeration.
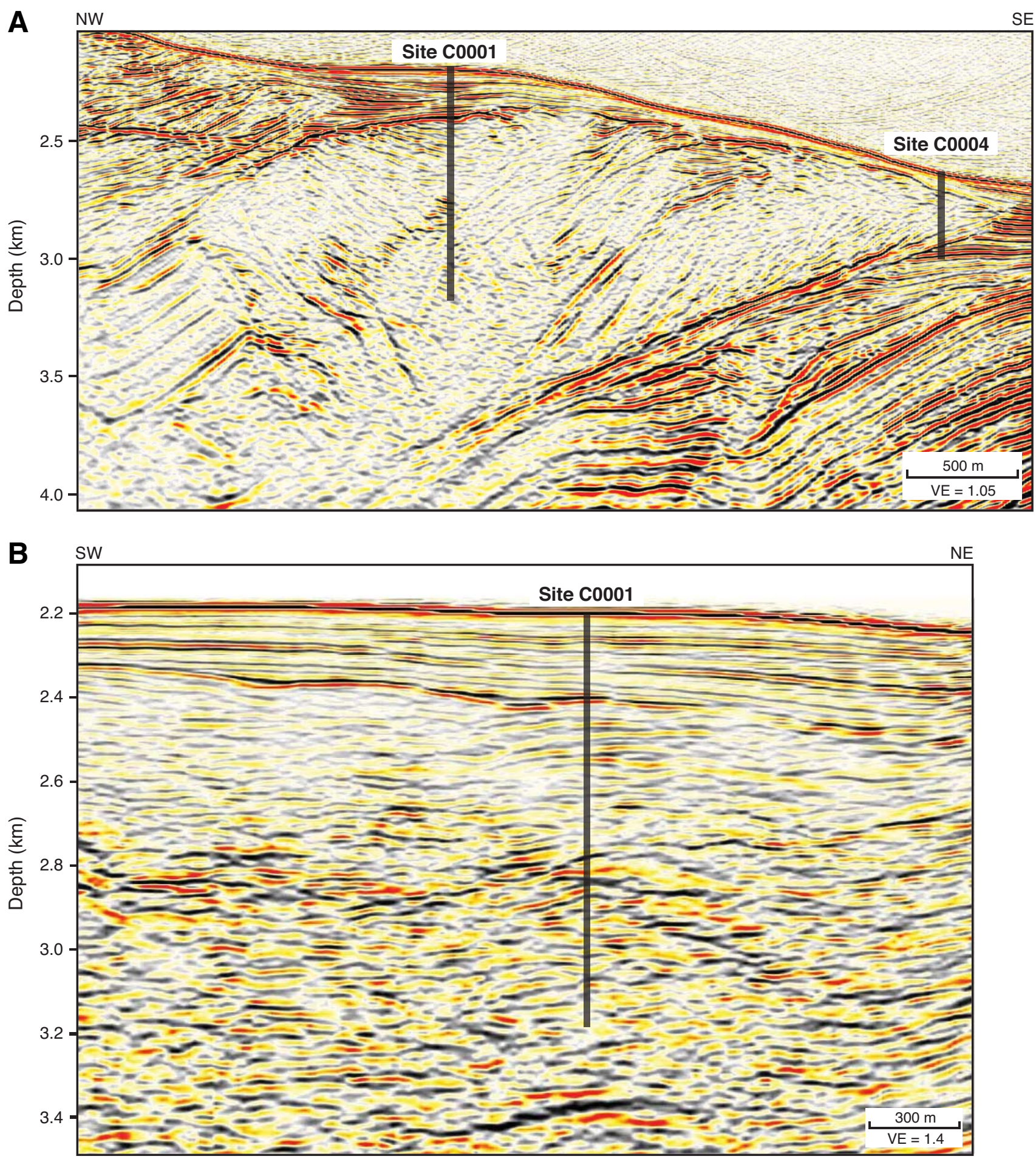
Figure F10. Hole locations, Site C0001. Solid lines = three-dimensional seismic line tracks.

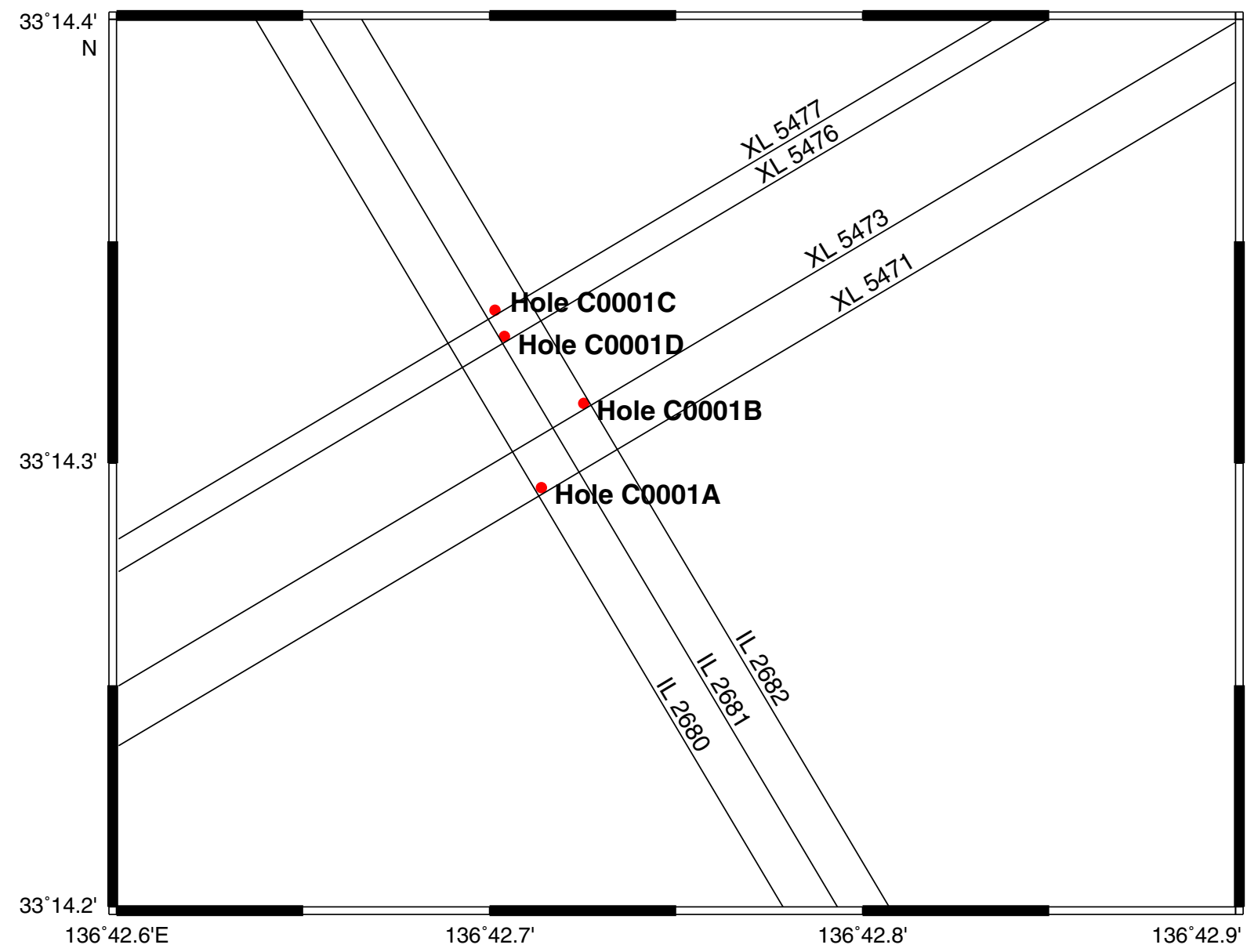




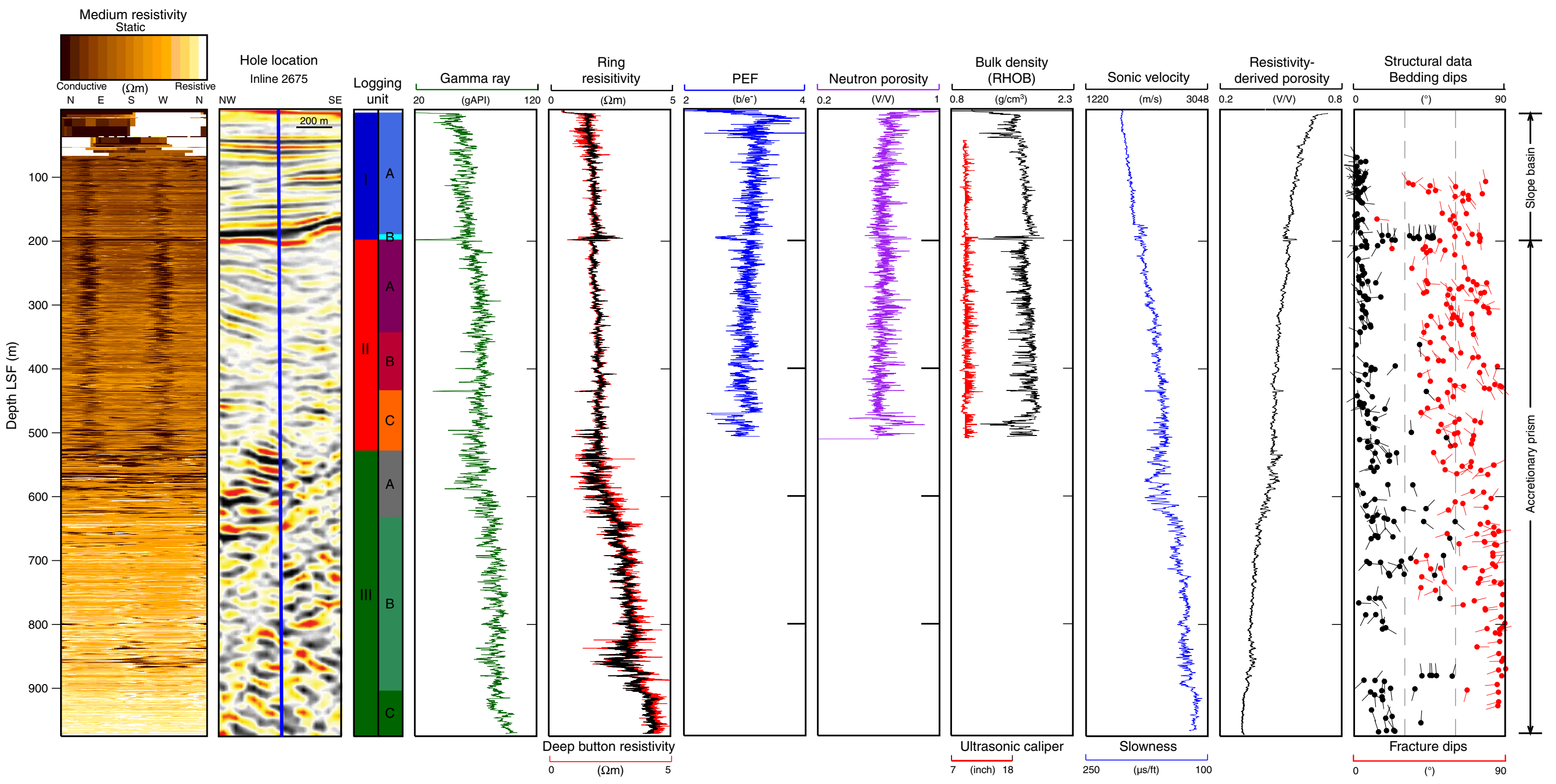


Figure F12. Three-dimensional seismic profile crossing Site C0002 (Moore et al., 2007). Profile locations plotted in Figures F2 and F13. A. Inline 2529. B. Cross-line 6225. BSR = bottom-simulating reflector, VE = vertical exaggeration.
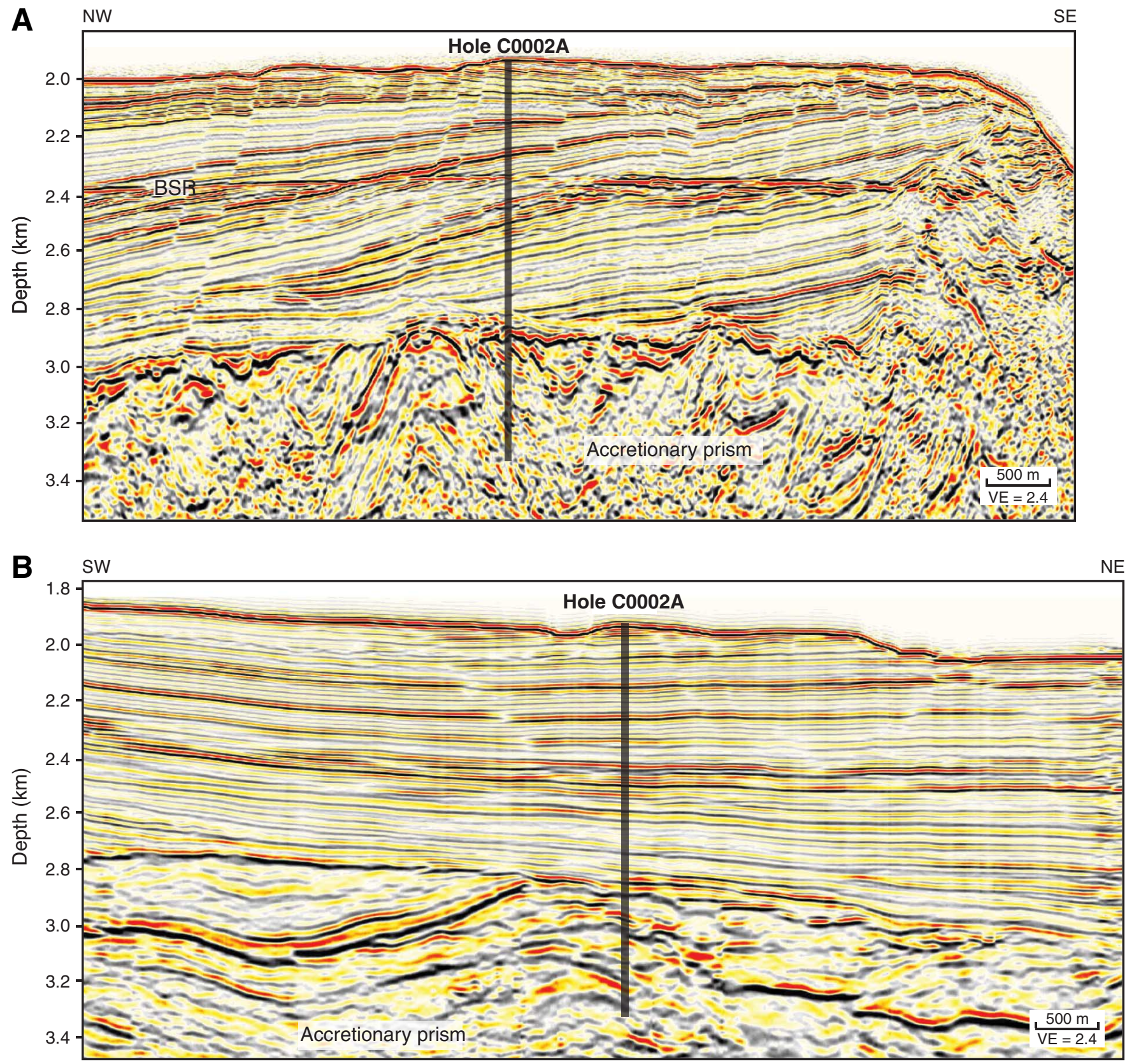
Figure F13. Summary log diagram, Site C0002. Bedding (black tadpoles) and fracture dips (red tadpoles) from resistivity at bit image. VE $=$ vertical exaggeration, $\mathrm{PEF}=$ photoelectric factor, $\mathrm{LSF}=\mathrm{LWD}$ depth below seafloor.

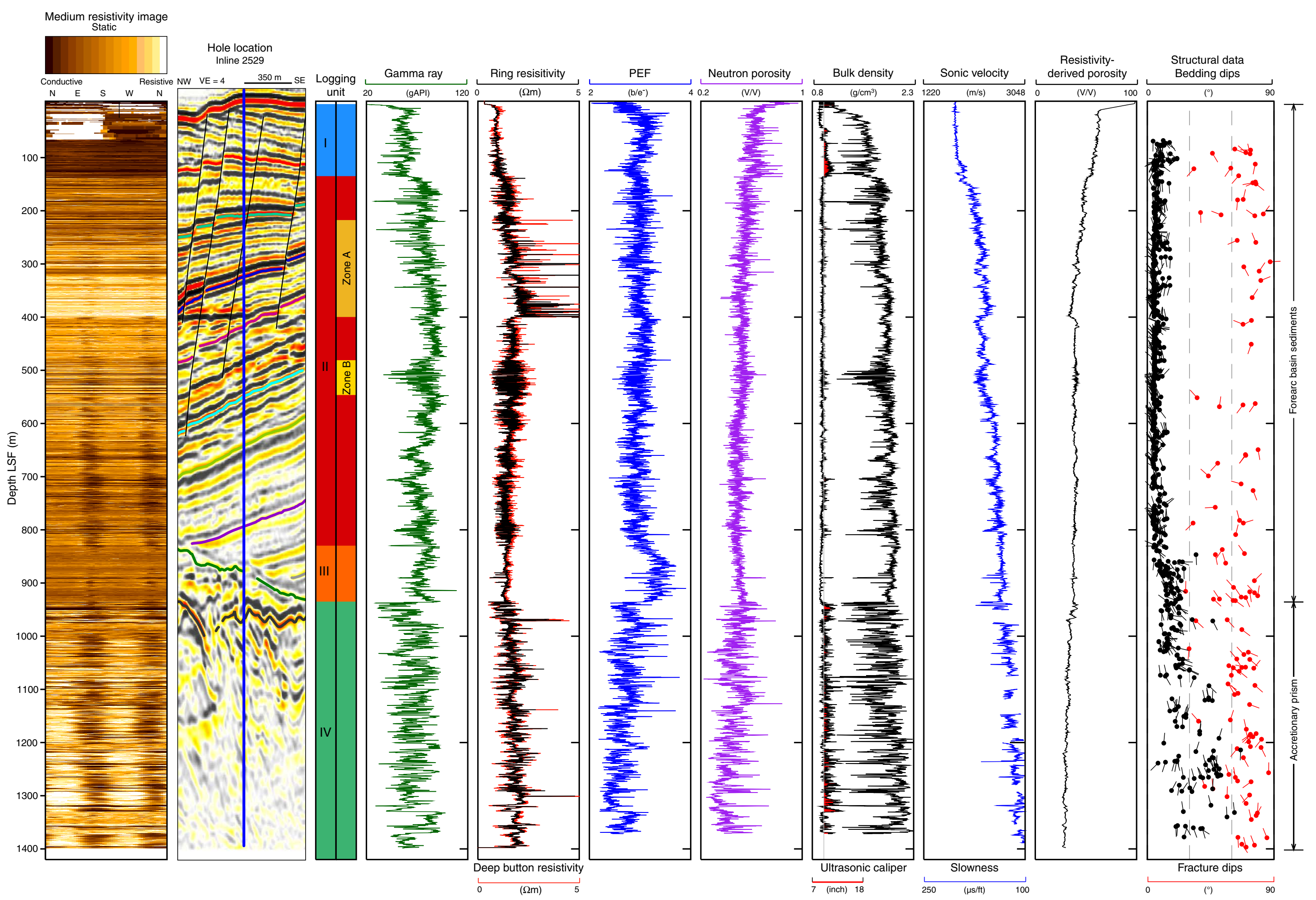


Figure F14. Three-dimensional seismic profile crossing Site C0003 (Moore et al., 2007). Profile location plotted in Figures F2 and F15. A. Inline 2596. B. Cross-line 5389. VE = vertical exaggeration.
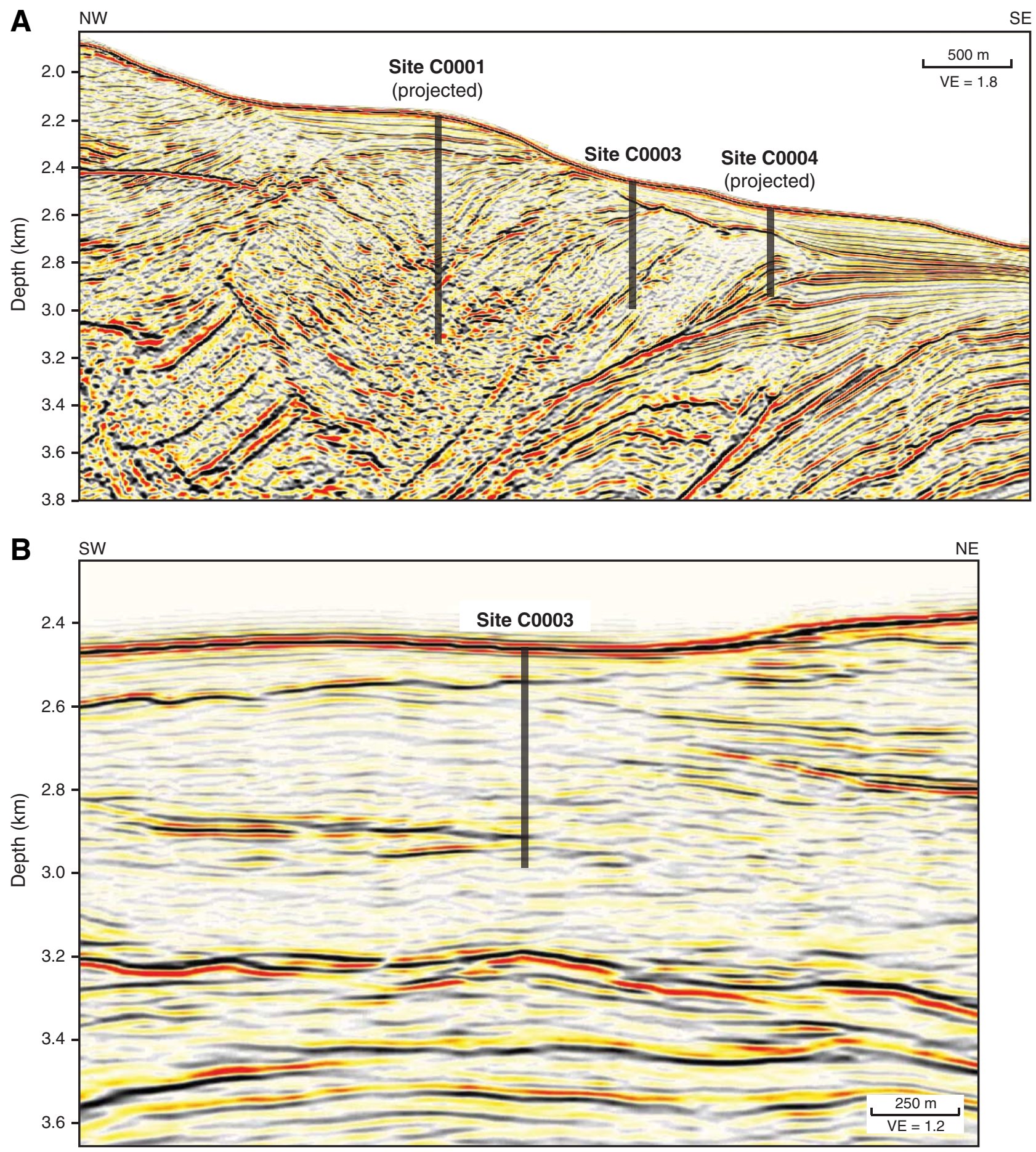

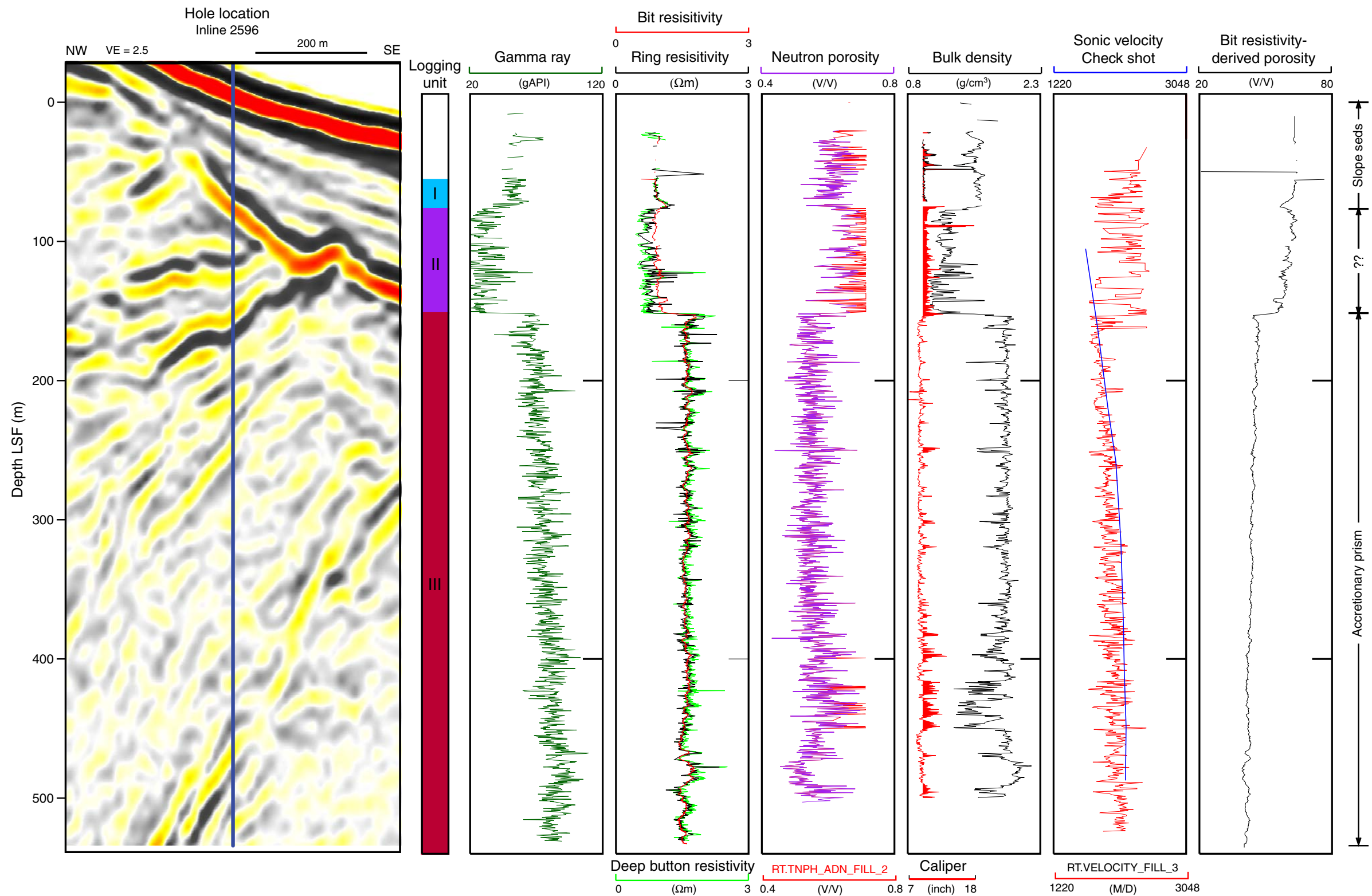
Figure F16. Three-dimensional seismic profiles crossing Site C0004 (Moore et al., 2007). Profile locations plotted in Figures F2 and F18. A. Inline 2596. B. Cross-line 5294. VE = vertical exaggeration.
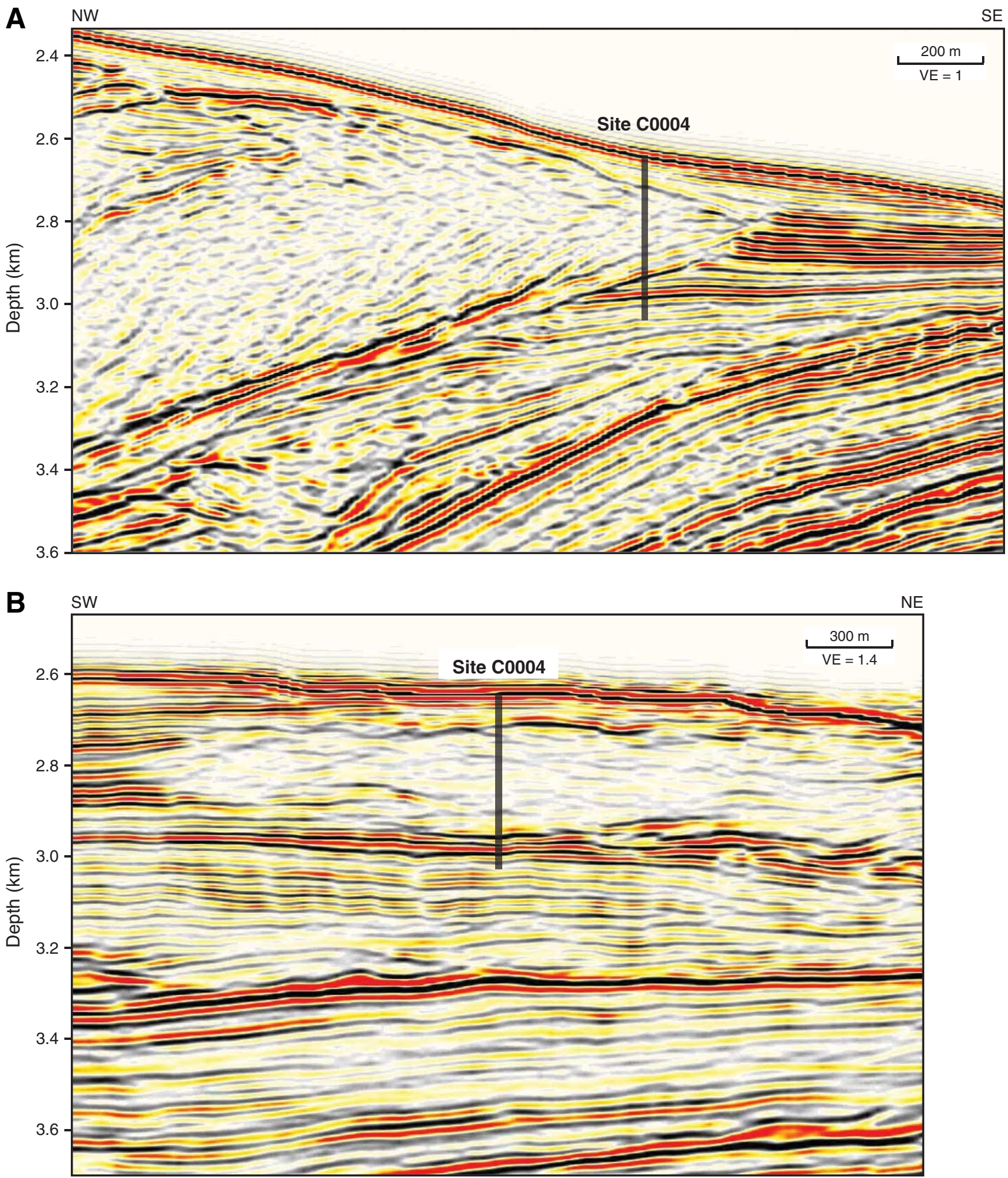
Figure F17. Hole locations, Site C0004. Solid lines = three-dimensional seismic line tracks.

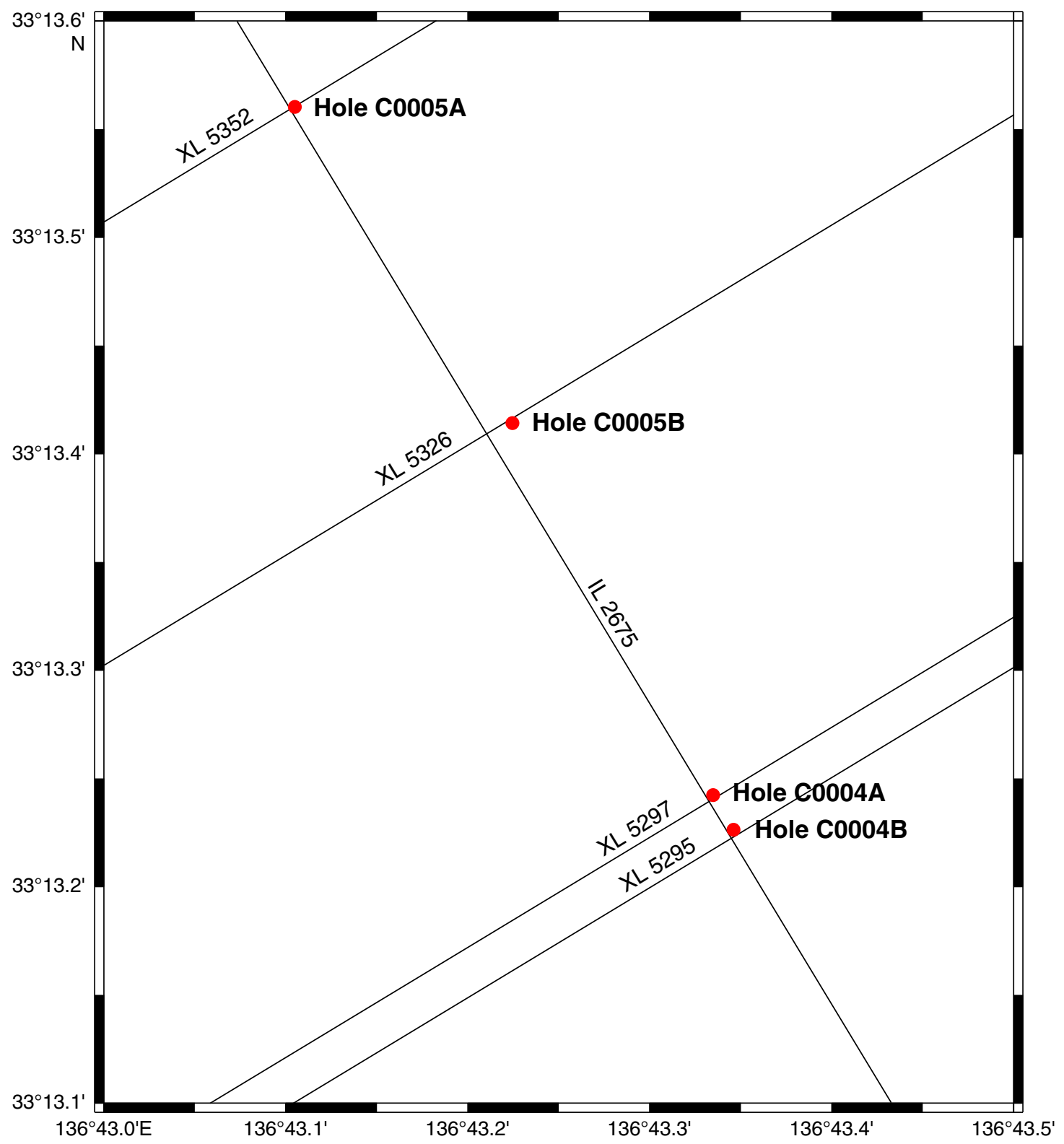



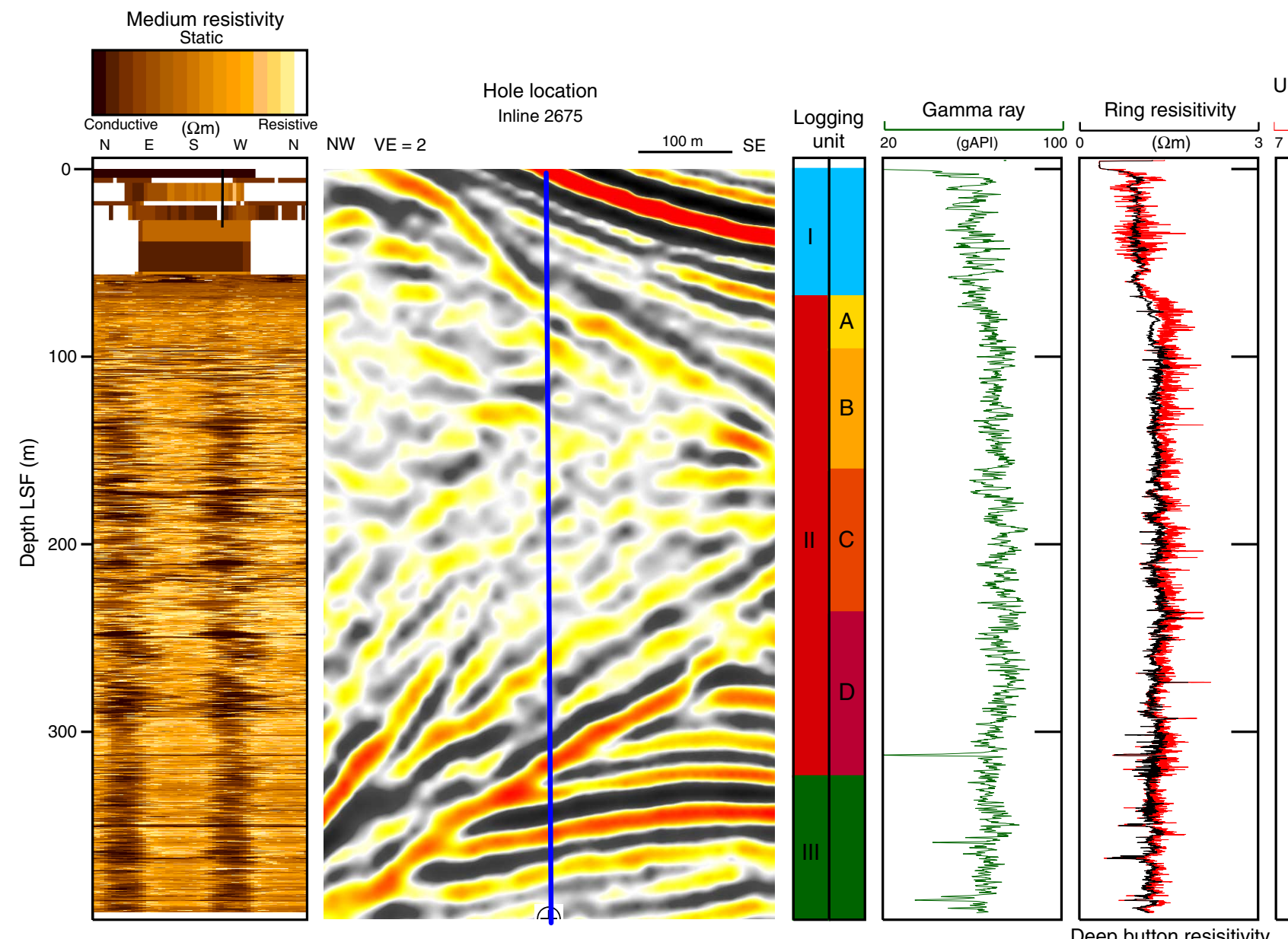

Ultrasonic

Resistivity-

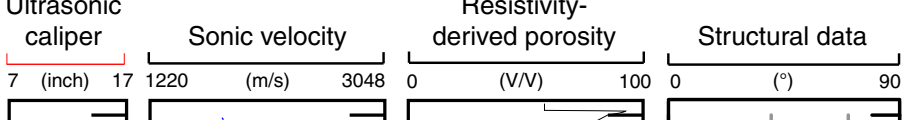

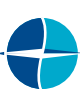

$\begin{array}{lll}0 & (\Omega \mathrm{m}) & 3\end{array}$
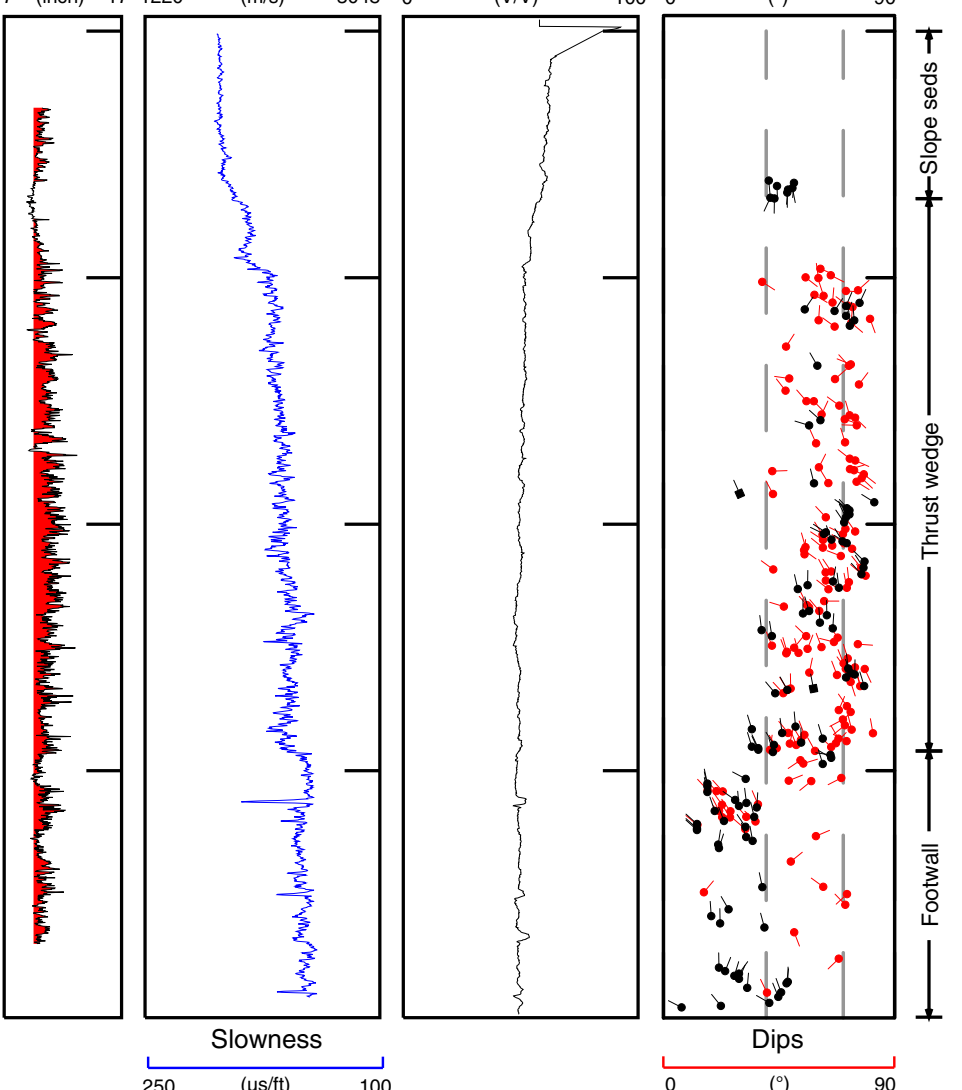
Figure F19. Three-dimensional seismic profile crossing Site C0006 (Moore et al., 2007) shown on Inline 2435. Profile location is plotted in Figure F2. VE = vertical exaggeration.

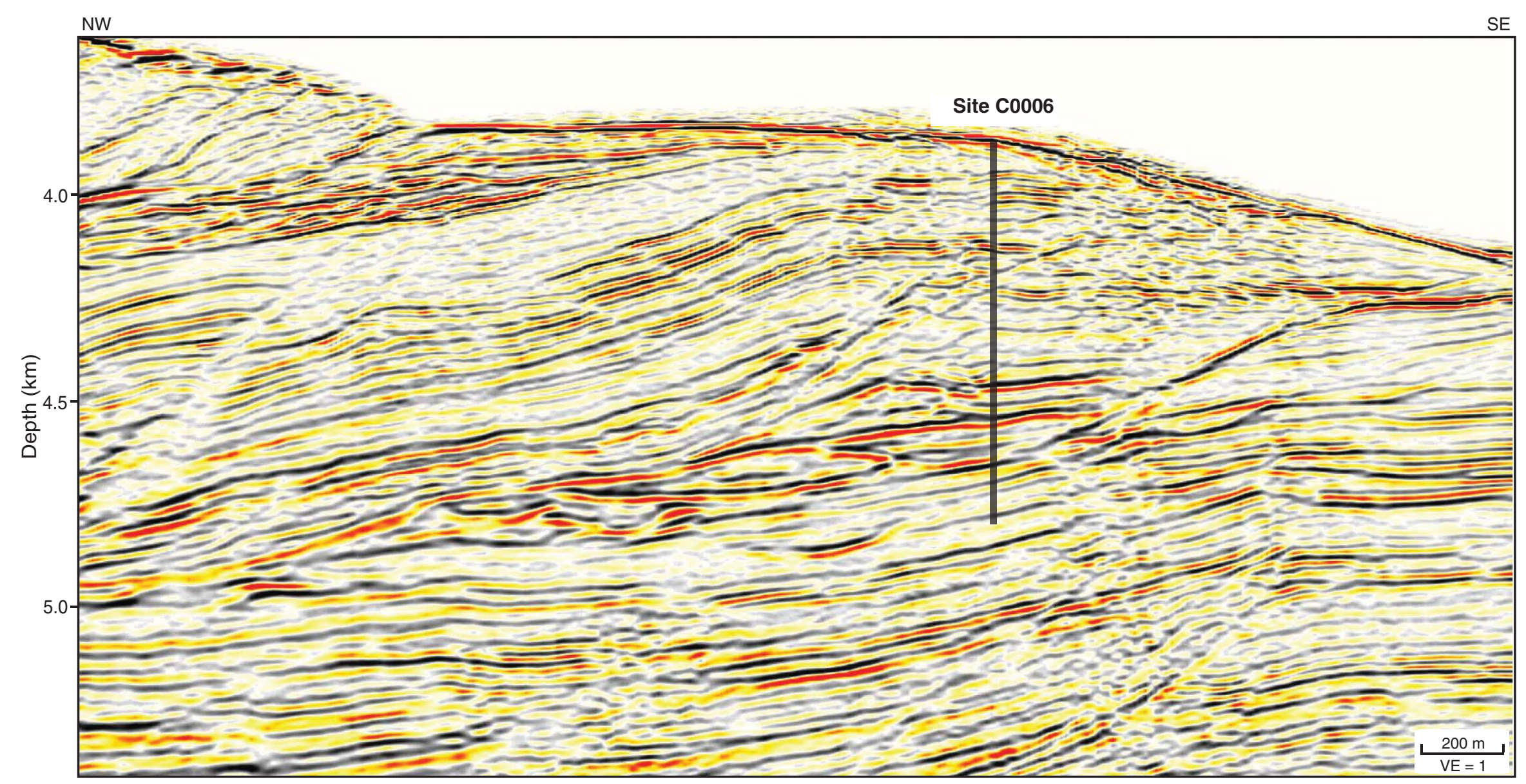


Figure F20. Summary log diagram, Site C0006. Bedding (black tadpoles) and fracture (red tadpoles) dip from resistivity at bit image. VE $=$ vertical exaggeration, LSF = LWD depth below seafloor.

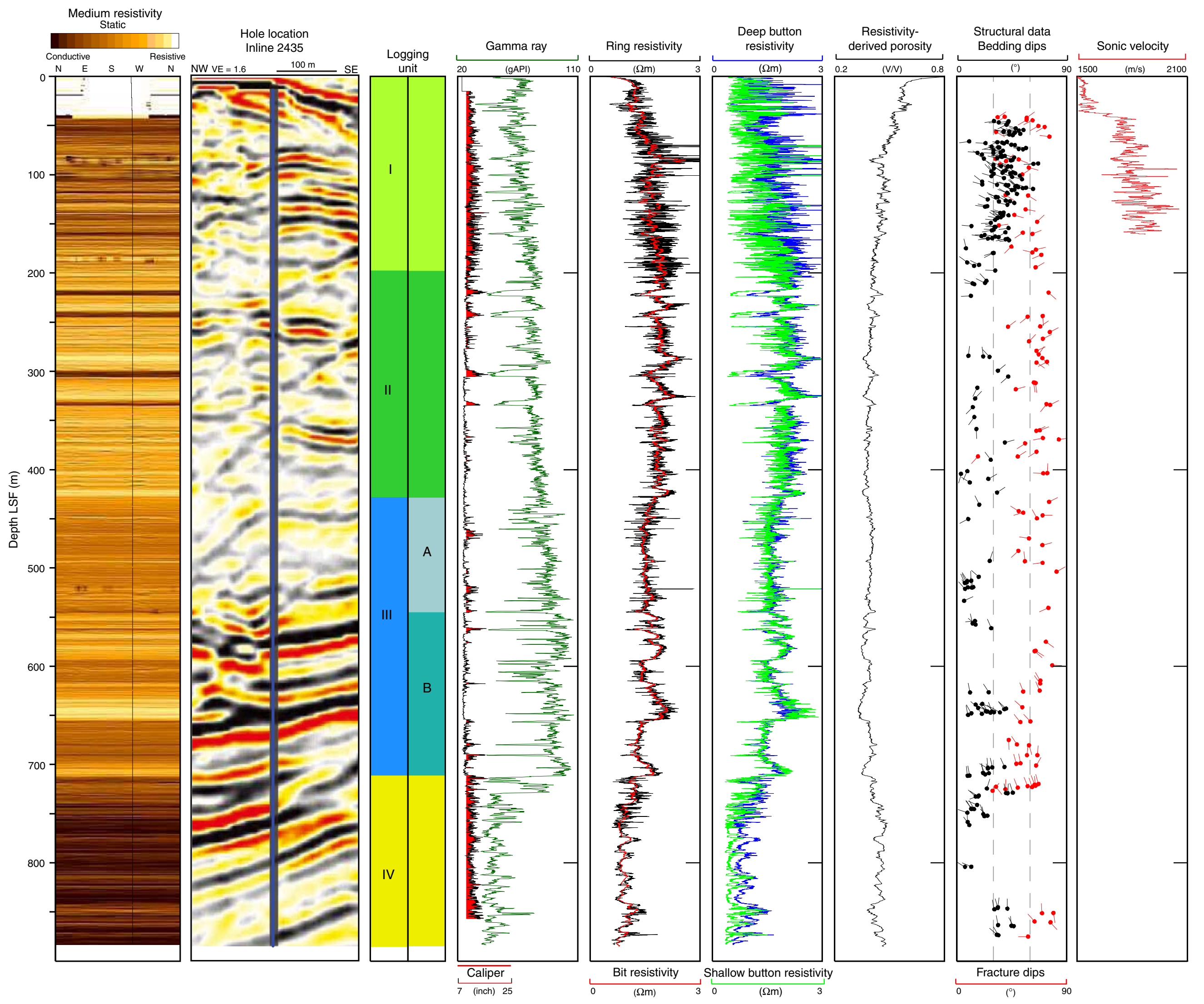


Figure F21. Lithologic summary for Expedition 314 LWD sites. LSF = LWD depth below seafloor.

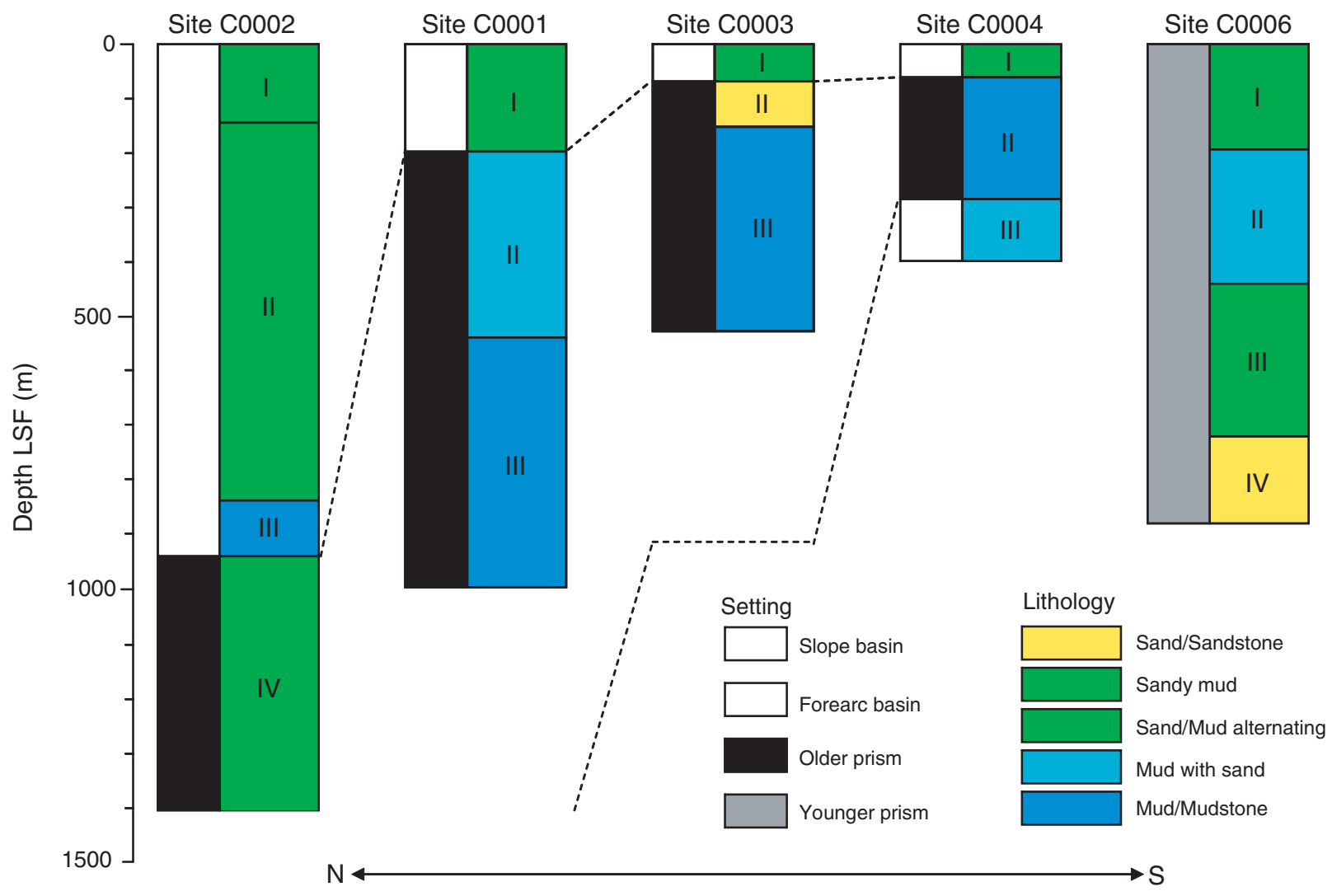


Figure F22. Borehole breakouts recorded in resistivity at bit images, Sites C0001, C0002, C0004, and C0006.

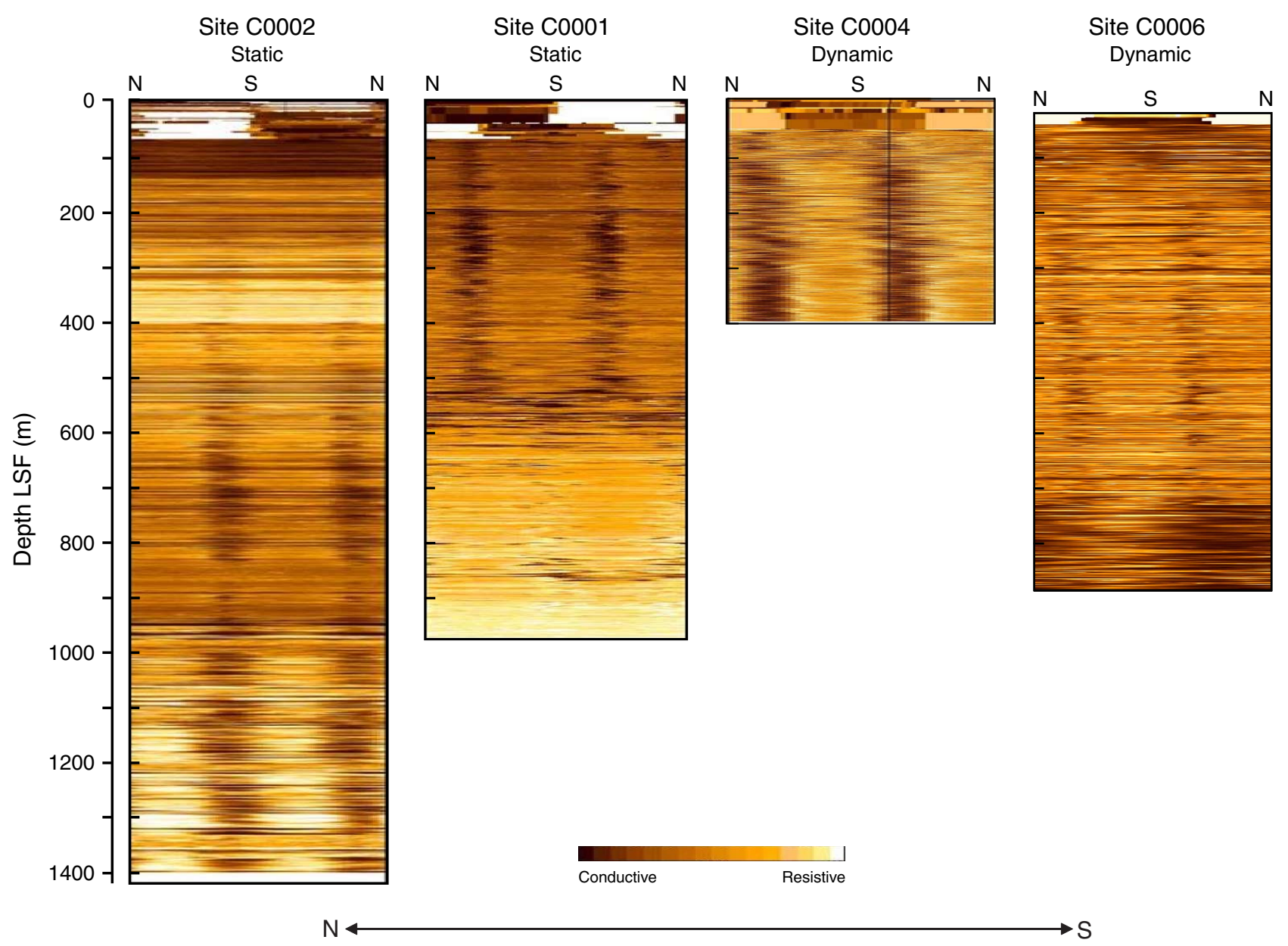


Figure F23. Azimuth of maximum principal horizontal stress estimated from borehole breakout images, Sites C0001, C0002 (in basin above 936 mbsf), C0004, and C0006 (red lines). Blue line = estimate for older accretionary prism formation below 936 mbsf at Site C0002.

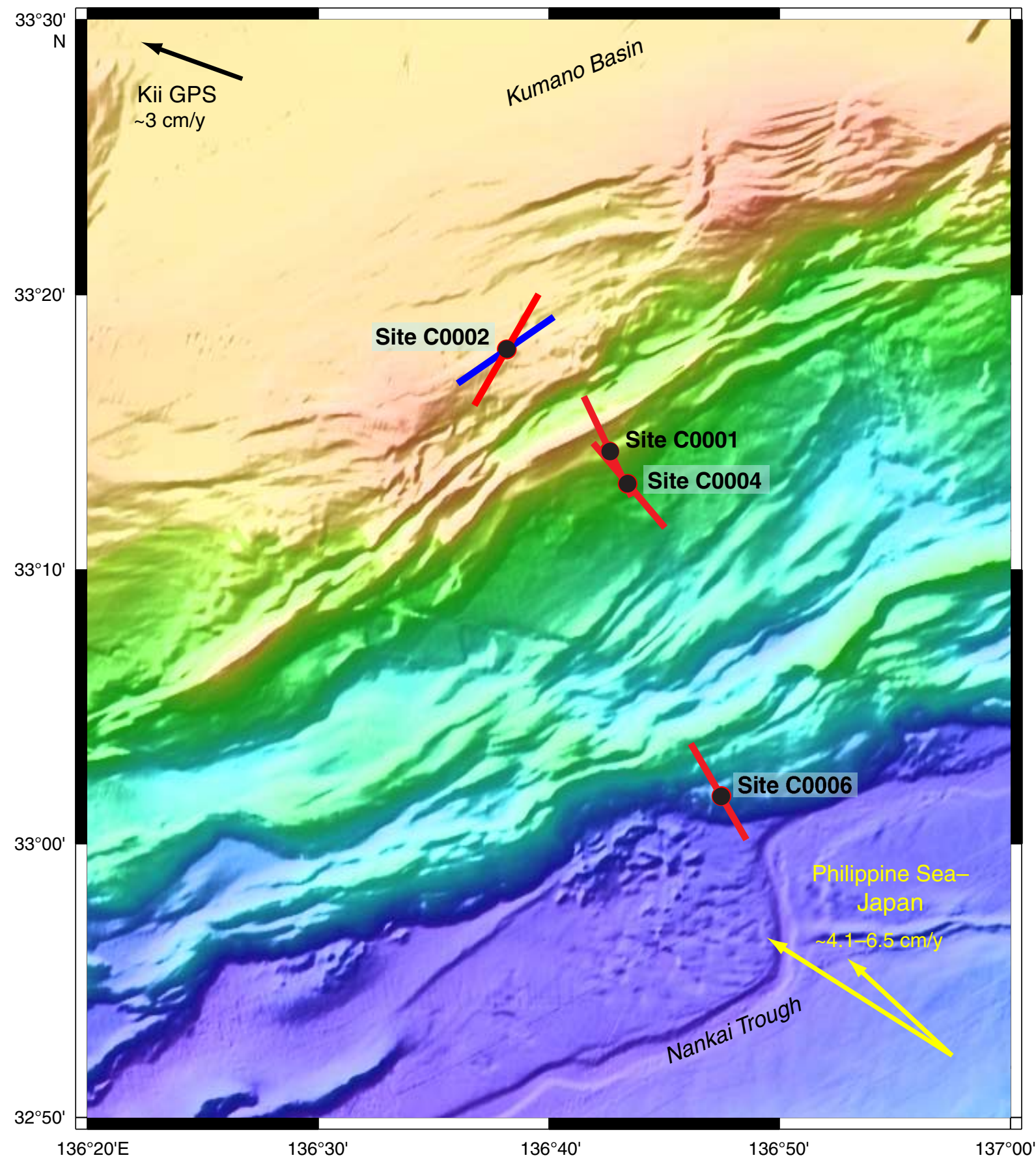


Figure F24. Gas hydrate zone at 250-400 mbsf at Site C0002 based on high-resistivity image (right panel), low gamma ray values, and high $P$-wave velocity log. Base of gas hydrate zone (400 m LSF) matches the bottomsimulating reflector (BSR) identified by the three-dimensional seismic data (left panel). LSF $=$ LWD depth below seafloor, $\mathrm{VE}=$ vertical exaggeration.

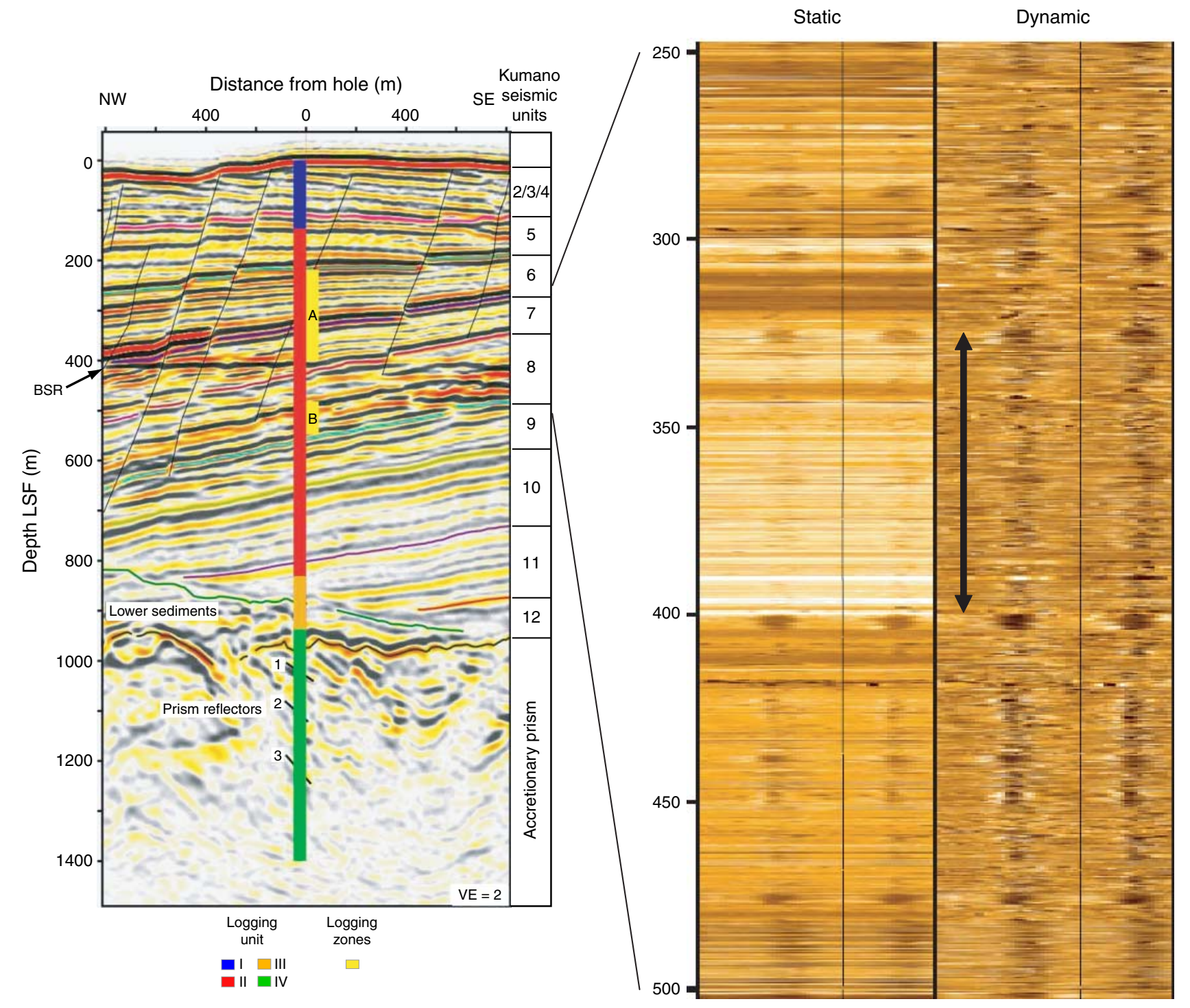


Table T1. Expedition 314 operations summary. (See table notes.)

\begin{tabular}{|c|c|c|c|c|c|c|c|}
\hline \multirow[b]{2}{*}{ Hole } & \multirow{2}{*}{$\begin{array}{l}\text { Proposed } \\
\text { site }\end{array}$} & \multirow{2}{*}{$\begin{array}{l}\text { Type of } \\
\text { drilling }\end{array}$} & \multicolumn{2}{|c|}{ Location } & \multirow{2}{*}{$\begin{array}{l}\text { Water } \\
\text { depth } \\
\text { (mbsl) }\end{array}$} & \multirow{2}{*}{$\begin{array}{l}\text { Drilled } \\
\text { depth } \\
\text { (m LSF) }\end{array}$} & \multirow[b]{2}{*}{ Remark } \\
\hline & & & Latitude & Longitude & & & \\
\hline \multicolumn{8}{|l|}{ 314- } \\
\hline C0001A & NT2-03B & Pilot & $33^{\circ} 14.2945^{\prime} \mathrm{N}$ & $136^{\circ} 42.7139^{\prime} \mathrm{E}$ & 2199.5 & 1000 & Pilot with MWD-GR-APWD \\
\hline C0001B & NT2-03B & Coring & $33^{\circ} 14.3135^{\prime} \mathrm{N}$ & $136^{\circ} 42.7252^{\prime} \mathrm{E}$ & 2189 & 30.6 & Geotechnical coring with HPCS \\
\hline C0001C & NT2-03B & LWD & $33^{\circ} 14.3345^{\prime} \mathrm{N}$ & $136^{\circ} 42.7014^{\prime} \mathrm{E}$ & 2198 & 77.5 & $\begin{array}{l}\text { Suspended because of deviation by strong } \\
\text { current }\end{array}$ \\
\hline C0001D & NT2-03B & LWD & $33^{\circ} 14.3286^{\prime} \mathrm{N}$ & $136^{\circ} 42.7040^{\prime} \mathrm{E}$ & 2197.5 & 976 & LWD (GVR-sonic-SVWD-MWD-APWD-ADN) \\
\hline $\mathrm{C} 0002 \mathrm{~A}$ & NT3-01B & LWD & $33^{\circ} 18.0192^{\prime} \mathrm{N}$ & $136^{\circ} 38.1810^{\prime} \mathrm{E}$ & 1936 & 1401.5 & LWD (GVR-sonic-SVWD-MWD-APWD-ADN) \\
\hline C0003A & NT2-01D & LWD & $33^{\circ} 13.3982^{\prime} \mathrm{N}$ & $136^{\circ} 42.1382^{\prime} \mathrm{E}$ & 2453 & 533.5 & LWD/Lost BHA \\
\hline C0004A & NT2-01I & Pilot & $33^{\circ} 13.2424^{\prime} \mathrm{N}$ & $136^{\circ} 43.3349^{\prime} \mathrm{E}$ & 2632 & 400 & Pilot without MWD-GR-APWD \\
\hline C0004B & NT2-01I & LWD & $33^{\circ} 13.2264^{\prime} \mathrm{N}$ & $136^{\circ} 43.3461^{\prime} \mathrm{E}$ & 2637 & 400 & LWD (GVR-sonic-SWWD-MWD-APWD) \\
\hline C0005A & NT2-01E & Pilot & $33^{\circ} 13.5603^{\prime} \mathrm{N}$ & $136^{\circ} 43.1050^{\prime} \mathrm{E}$ & 2446.5 & 524 & Pilot without MWD-GR-APWD \\
\hline C0005B & NT2-01G & Pilot & $33^{\circ} 13.4141^{\prime} \mathrm{N}$ & $136^{\circ} 43.2245^{\prime} \mathrm{E}$ & 2524.5 & 37 & Pilot without MWD-GR-APWD \\
\hline C0006A & NT1-03B & Pilot & $33^{\circ} 01.6430^{\prime} \mathrm{N}$ & $136^{\circ} 47.6550^{\prime} \mathrm{E}$ & 3875 & 885.5 & Pilot with MWD-GR-APWD \\
\hline C0006B & NT1-03B & LWD & $33^{\circ} 01.6350^{\prime} \mathrm{N}$ & $136^{\circ} 47.6390^{\prime} \mathrm{E}$ & 3871.5 & 885.5 & LWD (GVR-sonic-SWWD-MWD-APWD) \\
\hline
\end{tabular}

Notes: $L S F=L W D$ depth below seafloor. MWD = measurement while drilling, GR = gamma radiation, APWD = annular pressure while drilling, HPCS = hydraulic piston coring system, LWD = logging while drilling, GVR = geoVISION resistivity tool, sonic = sonic while drilling (sonicVISION), SVWD = seismicVISION while drilling, ADN = Azimuthal Density Neutron tool (adnVISION), BHA = bottom-hole assembly. 